Artigo original

Hegemonia - Revista Eletrônica de Relações Internacionais do Centro Universitário Unieuro

ISSN: $1809-1261$

UNIEURO, Brasília, número 14, 2014, pp. 25-87.

Recebido em: 2/6/2014

Avaliado em: 14/7/2014

Aprovado em: 28/8/2014

\title{
O Papel da Ameaça no Direito Internacional e a Securitização do Terrorismo nos Ataques de 11 de Setembro de $2001^{1}$
}

Ângelo Sousa Silva Freire² e Tágory Figueiredo ${ }^{3}$

Resumo: Os Estados possuem personalidade jurídica de Direito Internacional. Nessa condição, são titulares do direito à sobrevivência, sendo-lhes assegurada a adoção de medidas na garantia de sua existência. Sem embargo, a adoção de tais medidas deve suceder a identificação de uma injusta ameaça, real ou iminente, à sua integridade. Conforme a Teoria da Securitização, capitaneada por Barry Buzan e por Ole Wæver, a identificação e a posterior publicitação de uma ameaça nacional desdobra-se, progressivamente, mediante um processo de securitização, em cujo qual verificam-se categorias conceituais e unidades analíticas próprias. No evento histórico denominado Guerra do Afeganistão de 2001, caracterizado pelo conjunto de medidas militares adotadas, extraordinariamente (quanto à política interna), pelo governo norte-americano, após os ataques terroristas de 11 de setembro de 2001, verifica-se a ocorrência de todas as categorias conceituais e unidades de análise propostas pela Escola de Copenhagen, relativamente ao processo de securitização.

Palavras-chave: Segurança Internacional, Securitização, Afeganistão, 11 de setembro, Ato-discurso. e alterações.

Artigo elaborado a partir do trabalho de conclusão de curso do primeiro autor, com acréscimos significativos, correções Bacharel em Relações Internacionais. 


\section{Artigo original}

Hegemonia - Revista Eletrônica de Relações Internacionais do Centro Universitário Unieuro

ISSN: $1809-1261$

UNIEURO, Brasília, número 14, 2014, pp. 25-87.

ABSTRACT: States are International Law legal personalities. Under such condition, they are entitled to the right of survival and, therefore, authorized to adopt measures to secure their existence. Nevertheless, in order to have them adopted, States must primarily be able to identify and publicise an unjust threat, weather concrete or imminent, to its integrity. According to the Theory of Securitisation, which Barry Buzan and Ole Wæever have captained, identifying and posteriorly publicising a national threat comes into being through a progressive securitisation process. In the so-called Afghanistan War 2001, wherein military actions were taken extraordinarily (as far as internal politics are concerned) by the North-American government, after the 9/11 terrorist attacks, all the conceptual categories and analytical units, as proposed by the Copenhagen School, regarding the securitisation process.

Key words: International Security, Securitisation, Afghanistan, September 11th, Speech Act.

\section{INTRODUÇÃO}

No Brasil, não há muitos estudos relevantes sobre os desenvolvimentos teóricos da Escola de Copenhague voltados à Segurança Internacional. Após pesquisas sobre o tema, poucos trabalhos costumam ser encontrados ${ }^{4} \mathrm{e}$, mesmo entre eles, apenas alguns parecem dedicar-se, de fato, à aplicação das teorias e ao uso, na prática, dos aportes teóricos fornecidos pela sobredita Escola.

Merecem destaque o estudo de Grace Tanno (2003) e o de Marina Guedes Duque (2008). No primeiro, buscou-se tornar conhecido o papel da Escola de Copenhague, nos estudos de Segurança Internacional. No segundo, inclinado a uma verificação mais empírica, a autora apresenta um estudo de

Conforme consulta ao portal Google Scholar, em 10 out. 2013. 
Artigo original

Hegemonia - Revista Eletrônica de Relações Internacionais do Centro Universitário Unieuro

ISSN: $1809-1261$

UNIEURO, Brasília, número 14, 2014, pp. 25-87.

caso sobre a guerra do I raque à luz da teoria da securitização.

Em ambos, verifica-se que, entre os diversos conceitos produzidos pela Escola, deu-se maior ênfase ao conceito de securitização - muito útil para os fins a que se destinam o presente trabalho. Posto que, na segunda sessão do presente estudo, apresentar-se-á uma análise conceitual mais aprofundada, pode-se, desde logo, ainda que perfunctoriamente, postular que a securitização consiste um modelo conforme o qual as ameaças fazem-se percebidas e deslocadas de um nível de baixa relevância a um patamar de maior peso e, assim, autorizando a adoção de medidas emergenciais para conter o risco percebido.

Busca-se, neste trabalho, investigar se, com efeito, o arcabouço teórico da Escola de Copenhague é empiricamente suficiente para explicar a lógica do discurso norte-americano, no contexto da chamada Guerra ao Terror. Serão, nesse sentido, analisados os fenômenos que levaram o Afeganistão a ser percebido como uma ameaça aos Estados Unidos, a partir de setembro de 2001.

Apresentando alternativa teórica à perspectiva tradicional dos estudos de Segurança Internacional, responder-se-á a seguinte pergunta: como os atores securitizadores norte-americanos conseguiram deslocar o discurso sobre a questão afegã aos níveis emergenciais que acabaram justificando a aplicação de medidas bélicas de exceção?

Toma-se, como premissa, a noção de que a percepção de uma ameaça pode acarretar a construção de um discurso securitizador, para proteger a existência do objeto tido como ameaçado. Nesse sentido, a hipótese deste trabalho é que quanto maior for a adesão do público ao ato-discurso, proferido pelo ator securitizador, maior será a probabilidade de securitização de um objeto referente.

Inicialmente, far-se-á uma breve exposição teórica sobre a função da caracterização da ameaça, no Direito Internacional, como mecanismo legitimador da atuação extraordinária em defesa da sobrevivência dos Estados. Em seguida, apresentar-se-ão alguns fatos históricos relevantes sobre os 
Artigo original

Hegemonia - Revista Eletrônica de Relações Internacionais do Centro Universitário Unieuro

ISSN: $1809-1261$

UNIEURO, Brasília, número 14, 2014, pp. 25-87.

ataques ocorridos no território norte-americano, em 11 de setembro de 2001, e, sucessivamente, os que se seguem até a investida dos Estados Unidos no território afegão.

Em seguida, apresentar-se-á uma pesquisa bibliográfica de fontes secundárias - ex vi livros de leitura corrente e de referência e periódicos -, para fornecer uma contextualização da produção da Escola de Copenhague nos estudos de Segurança Internacional, proporcionando maior familiaridade com o tema, sobretudo no que diz respeito à securitização, em seus diversos níveis de análise.

Finalmente, far-se-á um estudo de caso, ponderando-se, sob a ótica do conceito de securitização, os discursos proferidos pelos atores securitizadores norte-americanos, relativamente à Guerra do Afeganistão. Para essa tarefa, serão utilizadas fontes bibliográficas primárias, tais como os próprios discursos oficiais dos tomadores de decisão.

Com vistas à maior objetividade possível, utilizar-se-á um recorte temporal do período que se localiza entre o fim da Guerra Fria e os dias atuais, tomando-se em conta o escopo específico deste estudo. Desse modo, o período em comento é o que se seguiu desde os ataques ao território dos Estados Unidos, em setembro de 2001, até a incursão da armada deste país no território afegão.

Para o estudo de caso, serão utilizadas as "lentes" do conceito de securitização, a fim de analisar a política externa norte-americana após os atentados de 2001. Com isso, pretende-se investigar a existência das unidades da análise da segurança envolvidas no processo de securitização.

Os recortes da teoria e do marco temporal serão feitos de modo a desdobrar-se o presente trabalho da maneira mais objetiva e menos ideologizada possível; portanto, não serão contempladas, no presente texto, as questões relacionadas à legitimidade da ação norte-americana, aos impactos de qualquer ordem no território ou na população afegã e, bem assim, ao período de duração da operação. 
Artigo original

Hegemonia - Revista Eletrônica de Relações Internacionais do Centro Universitário Unieuro

ISSN: $1809-1261$

UNIEURO, Brasília, número 14, 2014, pp. 25-87.

Serão fontes primordiais deste trabalho, as obras desenvolvidas por Barry Buzan e Ole Wæver, considerados fundadores da Escola de Copenhague e, até os dias atuais, o núcleo do desenvolvimento da teoria da securitização.

Os artigos de Marina Guedes Duque e de Grace Tanno, que também tratam, em termos gerais, do papel desempenhado pela Escola de Copenhague nos estudos em Segurança Internacional, servirão como suporte teórico complementar para o presente estudo. Devido a sua importância, tais textos serão recorrentemente mencionados; o que não deve significar, entretanto, que este trabalho se trata de mera reprodução do teor deles.

\section{A CARACTERIZAÇÃO DA AMEAÇA COMO PRESSUPOSTO DO DIREITO INTERNACIONAL À DEFESA DA EXISTÊNCIA DO ESTADO}

Já não encontra resistência, na literatura jurídica internacional, a percepção de que os Estados são sujeitos de direito internacional. A expressão implica reconhecer que os Estados possuem direitos e deveres, na esfera internacional do direito positivo. Nesse sentido, importa lembrar que o conceito de personalidade jurídica está, tradicionalmente, vinculado à percepção de que a pessoa possui aptidão para exercer direitos e para contrair obrigações.

Imprimindo hermenêutica extensiva à lição de De Plácido e Silva (1993, p. 360), verifica-se que os Estados possuem personalidade jurídica, em Direito Internacional, porque possuem aptidão para figurarem como sujeitos ativos ou passivos de direitos. É do reconhecimento da personalidade jurídica dos Estados que deriva a percepção de seu direito a uma existência própria, protegida pelo regramento jurídico da esfera em que se insere, no mundo fático. É razoável concluir que, por escorço interpretativo da lógica conceitual da personalidade jurídica, os Estados são, fundamentalmente, sujeitos ativos do direito à existência.

Para Shaw (2008), o direito internacional subjetivo que os Estados possuem a manter sua sobrevivência é corolário do rol de direitos fundamentais 
Artigo original

Hegemonia - Revista Eletrônica de Relações Internacionais do Centro Universitário Unieuro

ISSN: $1809-1261$

UNIEURO, Brasília, número 14, 2014, pp. 25-87.

que a eles foram conferidos, não somente pela literatura jurídica e pelo arcabouço normativo das relações internacionais, mas, também, pela própria dinâmica axiológica jus-internacionalista. Sua relevância é basilar na compreensão do status jurídico dos Estados no Direito Internacional, como corolário do direito fundamental à independência.

Perhaps the outstanding characteristic of a state is its Independence, or sovereignty. [...] Any political or economic dependence that may in reality exist does not affect the legal independence of the state, unless that state is formally compelled to submit to the demands of a superior state, in which case dependent status is concerned (SHAW, 2008, p. 211)

O direito de existência possui enorme relevância na hierarquia normativa do ordenamento jurídico internacional. Tanto o são que aprouve a seus representantes conferir-Ihes, por força da Carta das Nações Unidas, o direito de defender a incolumidade de seu território, de seu povo e de suas instituições governamentais soberanas, sempre que Ihes sobrevier qualquer ameaça, real ou iminente, conforme se depreende do artigo 51 da Carta das Nações Unidas, abaixo transcrito:

Nothing in the present Charter shall impair the inherent right of individual or collective self-defence if an armed attack occurs against a Member of the United Nations, until the Security Council has taken measures necessary to maintain international peace and security. (UNITED NATIONS, 1945).

Nessa linha de raciocínio, Accioly (2010) reconhece que aos Estados foi assegurado o direito de, inclusive, ferir a norma geral de não-intervenção, sempre que se caracterizar a imperiosidade de se tomar medidas para garantir o direito de defesa e de conservação de sua integridade existencial. $\mathrm{O}$ autor ressalva, sem embargo, que o mesmo artigo que autoriza os Estados a agir, 
Artigo original

Hegemonia - Revista Eletrônica de Relações Internacionais do Centro Universitário Unieuro

ISSN: $1809-1261$

UNIEURO, Brasília, número 14, 2014, pp. 25-87.

para defender sua incolumidade, desautoriza o excesso da legítima defesa, conforme verifica-se no trecho adiante transcrito.

[...] Não pode, contudo, tomar medidas capazes de atingir outro estado que não o ameace militarmente [...] não se justifica a prática de atos contra estado que possa ser considerado uma ameaça futura. Num caso, não existe intervenção, mas o exercício de atividade legítima; no outro, ocorrerá uma intervenção, como tal condenada pelo direito internacional. (ACCIOLY, 2010, p. 341).

Diante do exposto, pode-se concluir que embora o direito à sobrevivência possa ser garantido, legitimamente, mediante a tomada de ações militares de agressão, é imprescindível que o Estado caracterize a potencial lesividade da ameaça que Ihe aparece como pertinente.É dizer, nesse sentido, que, sempre que a um Estado competir tomar medidas de intervenção em outro Estado, igualmente soberano, deverão os atores de seus espaços institucionais de administração governamental, primeiramente, prover, à saciedade, elementos que comprovem a lesividade, real ou iminente, da ameaça apontada contra sua sobrevivência ou, em menor proporção, contra a incolumidade de um de seus elementos constitutivos (seu povo, seu território ou seu governo soberano).

\section{A GUERRA DO AFEGANISTÃO DE 2001}

O argumento central deste trabalho baseia-se na suposição de que a investida norte-americana no território afegão, em 2001, foi legitimada, no âmbito da política doméstica, por um processo bem-sucedido de securitização do terrorismo. Esse tema recebeu maior atenção, tanto interna quanto externamente, após a deflagração dos ataques e a tentativa frustrada, em território norte-americano em 11 de setembro de 2001.

A fim de analisar a veracidade da suposição proposta neste trabalho, 
Artigo original

Hegemonia - Revista Eletrônica de Relações Internacionais do Centro Universitário Unieuro

ISSN: $1809-1261$

UNIEURO, Brasília, número 14, 2014, pp. 25-87.

realizar-se-á, primeiramente, uma breve narrativa histórica dos fatos referentes ao que se convencionou chamar de 11/09. Demonstrar-se-á o processo de mobilização nacional até a efetiva incursão norte-americana em território afegão. No ultimo capítulo, os mesmos fatos serão observados segundo a perspectiva da Teoria da Securitização.

Os eventos de 11 de setembro de 2001

Quatro aviões foram sequestrados, em 11 de setembro de 2001, por dezenove militantes da al-Qaeda, uma organização internacional fundamentalista islâmica, constituída por células colaborativas e independentes. As aeronaves faziam voos comerciais e, portanto, continham, além da tripulação, passageiros civis.

Dos quatro aviões, dois atingiram as duas torres que formavam o complexo urbanístico denominado World Trade Center, na ilha de Manhattan, em Nova lorque. A terceira aeronave foi usada para atingir o Pentágono. Localizado em Washington, o complexo abriga o quartel general do Departamento de Defesa dos Estados Unidos.

A quarta e última aeronave caiu em um campo aberto, na zona rural do estado norte-americano da Pensilvânia. Em função de um atraso na decolagem, os passageiros tiveram tempo de ser informados, pelos noticiários, a respeito dos ataques realizados com as três outras aeronaves. Em estado de alerta, um grupo de passageiros e os comissários de bordo reuniram-se para tentar retomar o controle da aeronave. Todos morreram.

Não se sabe o alvo dos terroristas dessa aeronave, mas especula-se que poderia ter sido a Casa Branca - sede do governo norte-americano. Por terem perdido a própria vida, salvando a vida de outros milhares, desviando a aeronave da rota idealizada pelos terroristas, seus passageiros e seus 
Artigo original

Hegemonia - Revista Eletrônica de Relações Internacionais do Centro Universitário Unieuro

ISSN: $1809-1261$

UNIEURO, Brasília, número 14, 2014, pp. 25-87.

tripulantes são considerados heróis e foram homenageados no filme Voo United 93. ${ }^{5}$

O primeiro ataque aconteceu às 8 h45, horário local. Uma aeronave Boeing 747 da companhia aérea American Airlines colidiu contra a torre norte do World Trade Center. Centenas de pessoas morreram imediatamente, outras centenas ficaram presas nos andares acima do local da colisão - próximo ao oitavo andar.

A torre sul foi atingida, às 9h05, por uma aeronave com as mesmas características, que fazia o voo 175 da mesma companhia aérea. A colisão deuse em altura próxima à do sexagésimo andar e desencadeou uma significativa explosão. Enquanto tais eventos ocorriam, em Nova I orque, a terceira aeronave, em ato contínuo, com semelhantes características, atingiu o lado oeste do Pentágono, em Washington.

Após, aproximadamente, 15 minutos, a torre sul do World Trade Center, embora tendo sido construída para suportar ventos de até 320 quilômetros por hora e tipos convencionais de incêndio, desmoronou. ${ }^{6}$ Subiu uma gigantesca massa de poeira e de fumaça em meio à qual podia-se ver a segunda torre, de igual modo, ruir, ceifando a vida de milhares de pessoas, entre civis e integrantes de grupos de resgate, morreram naquele dia.

No momento dos ataques, o presidente dos Estados Unidos, que, na

GREENGRASS, Paul; BEVAN, Tim; FELLNER, Eric; LEVIN, Lloyd. Voo United 93. [Filme-vídeo]. Produção de Tim Bevan, direção de Paul Greengrass. Estados Unidos, Universal Pictures, 2006. Disponível em: $<<$ http://www.universalstudiosentertainment.com/united-93/>>

9-11 ATTACKS. A timeline of the events on September 11, 2001. Nova Iorque: History Channel, 20 de agosto de 2013. Programa de TV com informações dos ataques de 11 de setembro de 2001. Todos números e dados apresentados sobre o tema foram retirados dessa fonte. 
Artigo original

Hegemonia - Revista Eletrônica de Relações Internacionais do Centro Universitário Unieuro

ISSN: $1809-1261$

UNIEURO, Brasília, número 14, 2014, pp. 25-87.

época, era Sua Exa. o Sr. George Walker Bush, participava de evento educacional na Flórida. A equipe que realizava a sua segurança pessoal impediu-o de retornar a Washington, em função aos temores de que futuros ataques pudessem atingí-lo. (RICE, 2011)

Ao fim do dia, o presidente pronunciou-se perante a nação com relação aos ataques terroristas, nos seguintes termos:

Terrorist attacks can shake the foundations of our biggest buildings, but they cannot touch the foundation of America. These acts shattered steel, but they cannot dent the steel of American resolve. America was targeted for attack because we are the brightest beacon for freedom and opportunity in the world. And no one will keep that light from shining. (BUSH, 2001, p. 57)

Em seu artigo, "A Guerra Fria Acabou Duas Vezes", Carlos Gaspar argumenta que os eventos de 11 de setembro constituem um momento de definição. Segundo ele, o primeiro fim da Guerra Fria aconteceu dia 25 de dezembro de 1991 e trouxe mudanças de paradigmas históricos, como a queda de um império, o fim do comunismo e o fim da ordem mundial bipolar. Já o segundo fim, argumenta, aconteceu em 11 de setembro de 2001, embora não tenha tido a mesma magnitude do primeiro (GASPAR, 2003).

Os eventos desse chamado segundo fim ensejaram uma visibilidade sem precedentes que foi dada a um tema já presente nas discussões sobre Segurança Internacional, o terrorismo. Nas palavras dele, "a violência terrorista parece ter forçado uma mudança de paradigma na política internacional, para substituir Kant por Hobbes, ou mesmo por Schmitt." Os eventos dessa data expuseram a vulnerabilidade da superpotência à ofensiva estrangeira, de um modo apenas visto antes em 1941, após o ataque à base americana de Pearl Harbor (GASPAR, 2003, p. 144). 
Artigo original

Hegemonia - Revista Eletrônica de Relações Internacionais do Centro Universitário Unieuro

ISSN: $1809-1261$

UNIEURO, Brasília, número 14, 2014, pp. 25-87.

As reações aos eventos de 11 de setembro de 2001

Um luto de alcance nacional e demonstrações de patriotismo, relativamente às vítimas dos ataques, foram percebidos com intensidade na sociedade americana, nos dias posteriores aos ataques de 11 de setembro de 2001. ${ }^{7}$

Cidadãos comuns reuniram-se, em diversos lugares, para prestar homenagens aos mortos e aos feridos. As cerimônias incluíam, invariavelmente, o hasteamento da bandeira dos Estados Unidos. Carros, roupas e prédios estampavam o símbolo da nação americana. As pessoas estampavam a bandeira, nas filas para doação de sangue. Viu-se, de maneira generalizada, um sentimento de luto nacional.

Embora, em alguns casos, algumas pessoas aparentassem não saber, exatamente, o que estavam fazendo, não se podia duvidar da existência de um evidente senso de unidade e de compaixão. Entrevistado pelo jornal The New York Times, o jovem Mário Garcia relatou o seguinte:

I do not know why I have been coming here, except that I am confused [...] also a sense of unity. We all feel differently about what to do in response, but everybody seems to agree that we've got [sic] to be together, no matter what happens. So you get a little bit of hope in togetherness. (KI MMELMAN, 2001, p. 1)

O estado geral de comoção pode ser percebido, também, internacionalmente; sobretudo porque, entre os mortos, havia cidadãos de 80

9-11 ATTACKS. A timeline of the events on September 11, 2001. Nova Iorque: History Channel, 20 de agosto de 2013. Programa de TV com informações dos ataques de 11 de setembro de 2001. Todos números e dados apresentados sobre o tema foram retirados dessa fonte. 


\section{Artigo original}

Hegemonia - Revista Eletrônica de Relações Internacionais do Centro Universitário Unieuro

ISSN: $1809-1261$

UNIEURO, Brasília, número 14, 2014, pp. 25-87.

nacionalidades. No dia 13 de setembro, dois dias após os atentados, o periódico francês Le Monde veiculou a seguinte manchete: Nous sommes tous Américains. ${ }^{8} \mathrm{O}$ editorial indicava a adesão francesa ao sentimento de comoção que tomava conta da América e, dali, o mundo. ${ }^{9}$

Pessoas de diferentes países expressavam suas condolências. Chefes de Estado e de Governo emitiam notas e proferiam pronunciamentos, condenando os ataques e oferecendo auxílio, das mais variadas formas, ao governo dos Estados Unidos. Até o hino nacional americano chegou a ser executado, em outros países. No Brasil, painéis foram instalados com a imagem do Cristo Redentor abraçando as duas torres.

Os dezenove embaixadores da Organização do Tratado do Atlântico Norte (OTAN) emitiram nota declarando, publicamente, que os ataques aos Estados Unidos atingiram, na verdade, todas as nações que compõem a instituição. Embora não se tenha tomado nenhuma ação militar, como retaliação, o princípio da segurança coletiva foi invocado e propagado de maneira, talvez, sem precedentes. ${ }^{10}$

A resposta norte-americana aos ataques

Somos todos americanos. Tradução livre.

COLOMBANI, Jean-Marie. Nous sommes tous Américains. Le Monde. [Editorial] Paris: 13 set. 2001. Disponível em: <<http://www.lemonde.fr/idees/article/2007/05/23/nous-sommes-tous-americains_913706_3232.html>>. Acesso em: 10 out. 2013. 
Artigo original

Hegemonia - Revista Eletrônica de Relações Internacionais do Centro Universitário Unieuro

ISSN: $1809-1261$

UNIEURO, Brasília, número 14, 2014, pp. 25-87.

A retaliação norte-americana teve um caráter amplo. Direcionou-se, não somente, aos responsáveis pelos ataques perpetrados, em seu território, contra seus cidadãos e sua soberania. Foi levada a efeito, também, contra os países que abrigavam organizações terroristas. No pronunciamento à nação, em 11 de setembro, o Presidente Bush declarou guerra ao terrorismo e estabeleceu seu alvo. (DUQUE, 2008)

The search is underway for those who are behind these evil acts. I've redirected the full resources of our intelligence and law enforcement communities to find those responsible and to bring them to justice. We will make no distinction between the terrorists who committed these acts and those who harbor them (BUSH, 2001, p. 58).

Após os ataques, a população esperava que ações fossem tomadas, em relação à identificação e à punição adequada dos responsáveis pelos ataques. Em seu discurso, o Presidente Bush declarou, enfaticamente, que a justiça seria feita.

Em discurso proferido dia 20 de setembro, em sessão conjunta do Congresso norte-americano, o Presidente indicou os responsáveis pelos ataques. Segundo ele, as informações produzidas até aquele momento apontavam para uma rede terrorista conhecida como al Qaeda. A mesma organização responsável pelos bombardeios das embaixadas norte-americanas na Tanzânia e no Quênia, em 7 de agosto de 1998, e pelo bombardeio do contratorpedeiro USS Cole, em 12 de outubro de 2000, no porto de Aden, no lêmen. (BUSH, 2001)

Sob a liderança de Osama bin Laden, ainda de acordo com o pronunciamento do Presidente Bush perante o Congresso, existiam, espalhados em 60 países, milhares de terroristas tais como os que desferiram os ataques. Bush argumentou, ainda, que a liderança da rede al Qaeda possuía forte 
Artigo original

Hegemonia - Revista Eletrônica de Relações Internacionais do Centro Universitário Unieuro

ISSN: $1809-1261$

UNIEURO, Brasília, número 14, 2014, pp. 25-87.

influência no Afeganistão e apoiava o regime Talibão no controle do país - ou, pelo menos, em boa parte dele.

O Presidente deu um ultimato ao regime Talibão para que esse entregasse os terroristas e líderes da al Qaeda que estivessem abrigados em seu território.

And tonight, the United States of America makes the following demands on the Taliban: Deliver to United States Authorities all the leaders of al Qaeda who hide in your land. [...] Close immediately and permanently every training camp in Afghanistan, and hand over every terrorist, and every person in their support structure, to appropriate authorities. [...] They will hand over the terrorists, or they will share in their fate (BUSH, 2001, p. 67). (grifo nosso)

Consoante ao pronunciamento feito logo após os ataques, em 11 de setembro, nesse discurso, perante o Congresso, o George W. Bush enfatizou o posicionamento norte-americano relativamente à ameaça do terrorismo, estipulando um prazo para que fossem entregues os terroristas. Deixou bem claro que os Estados Unidos respeitavam os cidadãos afegãos, observando que, à época, era o maior fornecedor de ajuda humanitária àquele país. Não obstante a isso, ressaltou que seu país condenava o regime Talibão, suas práticas repressivas contra a população e o suporte, de qualquer natureza, a terroristas.

Em 14 de setembro, o Congresso norte-americano aprovou uma resolução intitulada Senate Joint Resolution 23 - Authorization for Use of Military Force Against Terrorists (AUMF) ${ }^{11}$, autorizando o Presidente a usar toda

Resolução Conjunta do Senado nº 23 - Autorização para o Uso de Força Militar contra Terroristas 
Artigo original

Hegemonia - Revista Eletrônica de Relações Internacionais do Centro Universitário Unieuro

ISSN: 1809-1261

UNIEURO, Brasília, número 14, 2014, pp. 25-87.

força militar necessária e apropriada contra aquelas nações, organizações ou indivíduos que, segundo o seu julgamento, tivessem planejado, autorizado, cometido ou ajudado nos ataques terroristas de 11 de setembro ou, até mesmo, abrigado tais organizações ou pessoas.

Caso não fossem atendidas as demandas apresentadas, pelo Presidente, aos líderes do regime Talibão, os Estados Unidos dariam início a ataques contra alvos localizados no Afeganistão.

On my orders, the United States military has begun strikes against al Qaeda terrorist training camps and military installations of the Taliban regime in Afghanistan. These carefully targeted actions are designed to disrupt the use of Afghanistan as a terrorist base of operations, and to attack the military capability of the Taliban regime (BUSH, 2001, p. 75).

Em 7 de outubro, os Estados Unidos, mesmo sem o aval das Nações Unidas, em operação conjunta com militares da Grã Bretanha, do Canadá, da Alemanha e da França, iniciaram a operação militar que tornou-se conhecida como a Guerra do Afeganistão. Em um primeiro momento, essas potências auxiliaram a denominada Aliança do Norte, ${ }^{12}$ fornecendo apoio logístico, tático e aéreo. (DUQUE, 2008)

As primeiras tropas do exército norte-americano chegaram tão somente em 20 de outubro. Em 13 de novembro, essas tropas tomaram a capital afegã, Cabul. Os principais objetivos da investida eram destituir o governo do regime Talibão, capturar os líderes e os responsáveis pelos ataques de 11 de setembro e, finalmente, expulsar a al Qaeda do Afeganistão.

Grupo que se opunha ao regime Talibão 
Artigo original

Hegemonia - Revista Eletrônica de Relações Internacionais do Centro Universitário Unieuro

ISSN: $1809-1261$

UNIEURO, Brasília, número 14, 2014, pp. 25-87.

Os objetivos foram cumpridos com rapidez. O regime Talibão foi vencido, os líderes da al Qaeda foram presos e as bases terroristas foram bombardeadas; entretanto, a guerra contra o terrorismo ainda continuaria por muito tempo e açambarcaria, também, outros países. ${ }^{13}$

A ESCOLA DE COPENHAGUE: Os estudos sobre segurança internacional

Profundas mudanças, em diversas áreas das Relações Internacionais, marcaram o final da década de 1980 e o início da década de 1990. Charles Hermann, em artigo publicado no início da década de 1990, foi enfático ao escrever "nós estamos em um período de profunda mudança nas Relações Internacionais e política externa" (HERMANN, 1990, p.3).

Semelhantemente, Hoffmann, em 1989, havia notado que "há períodos, na história, nos quais profundas mudanças ocorrem de forma brusca, quando os acontecimentos desenvolvem-se tão rapidamente que as análises feitas por especialistas tornam-se obsoletas antes mesmo de serem impressas." Segundo ele, o fim da década de 1980 era um desses períodos (apud Hermann, 1990, p.4).

Outros temas marcaram as principais mudanças durante essas duas décadas. A exemplo disso, podem ser citadas: a redistribuição do poder mundial, que voltou à unipolaridade, a partir da emergência dos Estados Unidos como potência mundial; as mudanças no Sistema Internacional advindas do novo arranjo de poder; a vitória do capitalismo sobre o comunismo; a dissolução da potência socialista; a

SHANKER, Thom; SCHMITT, Eric. A Nation Challenged: Military Campaign; Taliban Defeated, Pentagon Asserts, But War Goes On. The New York Times. Nova Iorque, p. B4, 11 dez. 2001. Disponível em: <<-l>>. Acesso em: 25 out. 2013. 
Artigo original

Hegemonia - Revista Eletrônica de Relações Internacionais do Centro Universitário Unieuro

ISSN: $1809-1261$

UNIEURO, Brasília, número 14, 2014, pp. 25-87.

emergência de novos atores, tais como entidades transnacionais e organizações internacionais não-governamentais.

[...] better understanding of political change is obtained by analysing the relations beween governments and many other actors from each country. Global politics also includes companies and non-governmental organizations (NGOs). [...] All these actors play a regular part in global politics and each government interacts with a range of non-state actors. (WILLETS, 2011, p. 328)

Grace Tanno (2003) destaca que, em Relações Internacionais, "eventos históricos tendem a engendrar desenvolvimentos da teoria". O surgimento do campo de estudos das Relações Internacionais e o desenvolvimento de grande parte de suas teorias ocorreram durante um importante evento histórico, a Grande Guerra do Século XX - para utilizar a definição de Tanno. Não é difícil concluir, nesse sentido, que outro grande evento histórico, o fim da Guerra Fria, engendre as mudanças e a compreensão do mundo, em seu tempo.

As mudanças ocorridas nos estudos de Segurança Internacional e a contribuição teórica da Escola de Copenhague, nesse período, constituem o foco da abordagem deste estudo. Consequentemente, a fim de contextualizar o surgimento dessa Escola, como vertente teórica, em Segurança Internacional, neste capítulo apresentar-se-á um breve histórico dos estudos em segurança e, logo em seguida, apresentar-se-ão os desenvolvimentos teóricos produzidos em Copenhague, além de seus principais conceitos.

A ampliação do conceito de segurança internacional

No período da Guerra Fria, o sistema bipolar constituiu as bases da estrutura do poder mundial. Nele, cada uma das duas superpotências - a saber, 
Artigo original

Hegemonia - Revista Eletrônica de Relações Internacionais do Centro Universitário Unieuro

ISSN: $1809-1261$

UNIEURO, Brasília, número 14, 2014, pp. 25-87.

os Estados Unidos e a União Soviética - capitaneava uma coalizão de Estados aliados e competia pelo congraçamento de tantos mais Estados não-alinhados quanto possível (HUNTINGTON, 1999).

O fim da Guerra Fria, emblematicamente representado pela queda do muro de Berlim, em 1989, representou o fim da divisão ideológica do mundo entre Ocidente e Oriente. De tal fato decorreram profundas mudanças nos estudos sobre segurança internacional, uma vez que os limites interpretativos e a capacidade preditiva de seus principais modelos teóricos foram desafiados.

A gênese do campo de estudos de Segurança Internacional deu-se ao longo do século $X X$, assim como os estudos em Relações Internacionais. $O$ desencadeamento de vários conflitos marcou esse contexto; entre os quais, com maior destaque, as duas maiores guerras da era moderna (1914 e 1939). Sob a influência direta dessa conjuntura política internacional, o realismo ${ }^{14}$ figurou, de forma mais intensa, no pós-Segunda Guerra Mundial, como paradigma predominante, sobretudo nos Estados Unidos. (TANNO, 2003)

Segundo Sarfati (2005), a imagem realista - ligada à vertente tradicional dos estudos de segurança internacional - baseia-se em quatro premissas: a) Os Estados são os principais atores das relações internacionais; b) Os Estados são atores unitários; c) Os Estados são essencialmente atores racionais; d) Conforme o grau de importância, há uma hierarquia nos assuntos de relações internacionais. (SARFATI, 2005, pgs. 63-72; 87-99)

Para os realistas, ${ }^{15}$ o Estado, além de ser a unidade básica de análise nas

Nome com que se designa uma das principais correntes teóricas das Relações Internacionais daquela época. 
Artigo original

Hegemonia - Revista Eletrônica de Relações Internacionais do Centro Universitário Unieuro

ISSN: $1809-1261$

UNIEURO, Brasília, número 14, 2014, pp. 25-87.

Relações Internacionais, também é o ente mais relevante nos planos interno e internacional. Os atores não estatais, por sua vez, detêm status pouco relevante na análise internacionalista, pois, presumidamente, estes não possuem uma base territorial - prerrogativa exclusiva dos Estados -, além disso, suas ações, de novo, presumidamente, submetem-se ao crivo do ator principal, o Estado.

Pautada no Realismo e, segundo Tanno (2003), associando "segurança, exclusivamente, ao Estado e aos aspectos militares e estratégicos", a análise da segurança internacional, nos anos finais da Guerra Fria, tornaram-se míopes e limitadas, pois não conseguiam congregar, em sua análise, temas importantes sobre a realidade internacional.

As críticas proferidas contra o paradigma realista, acompanhadas de manifestações que defendiam a ampliação do conceito de segurança, iniciaramse ainda na década de 1980; entretanto, tais proposições não obtiveram maior êxito porque não se tratavam, para grande parte dos teóricos e analistas da época, de uma discussão plausível. Um dos primeiros autores a escrever sobre a definição míope da segurança foi Richard Ulan, que destacou o seguinte:

[...] definir segurança nacional em termos puramente militares exprime uma ideia profundamente falsa da realidade. Tal imagem é duplamente enganosa, e, com isso, igualmente perigosa. Em primeiro lugar, faz os Estados se concentrarem em ameaças militares e ignorarem outros tipos de ameaças, talvez até mais danosas. Por consequência, há a redução da segurança total deste Estado. Em segundo lugar, contribui para uma militarização generalizada das relações internacionais, o que, no longo prazo, apenas aumenta a insegurança global. (ULLMAN, 1983, p. 129). ${ }^{16}$ 
Artigo original

Hegemonia - Revista Eletrônica de Relações Internacionais do Centro Universitário Unieuro

ISSN: $1809-1261$

UNIEURO, Brasília, número 14, 2014, pp. 25-87.

O fenômeno da globalização emergiu como resultado do esgotamento do sistema da Guerra Fria, marcado pelo equilíbrio de poder entre Estados Unidos e a URSS e pelo confronto entre comunismo e capitalismo ${ }^{17}$. A globalização caracterizou-se pelo caráter dinâmico, contínuo e promotor da cooperação entre mercados, Estados e tecnologias. É o sistema em que, embora figurem, ainda, como o principal objeto de análise, nas Relações Internacionais, os Estados não são mais os únicos. Nesse sistema, dividem espaço com atores que extrapolam, literalmente, as fronteiras dos Estados nacionais - os denominados atores transnacionais (FRIEDMAN, 1999).

Esse contexto marcou a formação de novos desafios impostos, pela realidade do Sistema Internacional, à eficácia interpretativa e à capacidade preditiva do paradigma então dominante, o Realismo. Tais desafios decorreram do impacto provocado por alguns temas que, até então, eram tidos, pelos realistas, como irrelevantes, na segurança internacional.

A partir dessa constatação e com o cenário favorável, iniciou-se um processo de inclusão gradual de temas não-militares, na agenda de segurança internacional, tais como: economia, ecologia, meio ambiente, demografia, fatores domésticos da segurança, recursos e ameaças transnacionais (MATHEWS, 1989; ULLMAN, 1983; NAíM, 2003; HAFTENDORN, 1991).

A emergência de uma realidade que colocasse à prova o paradigma predominante até então engendrou questionamentos e intensificou a procura por uma nova agenda de pesquisa na área. Essa busca serviu de estímulo ao debate entre teóricos com abordagens já existentes e, consequentemente, a

Não há consenso na literatura quanto a definição do que vem a ser globalização. Por isso, para fins deste trabalho, a definição dessa temática será a fornecida por Sarfati (2005). Segundo ele, a globalização pode ser definida como "o processo no qual as tradicionais barreiras entre os Estados caem, fruto do avanço tecnológico, que possibilita intensa troca de informações entre as pessoas do mundo." Sendo esta um processo, será feito um recorte que proporcione melhor visualização desse processo quando da transição da Guerra Fria para o período pós-Guerra Fria. O recorte feito evidencia a definição de Friedman destacada acima. 
Artigo original

Hegemonia - Revista Eletrônica de Relações Internacionais do Centro Universitário Unieuro

ISSN: $1809-1261$

UNIEURO, Brasília, número 14, 2014, pp. 25-87.

formulação de novas propostas epistemológicas. Naturalmente, redefiniu-se o conceito de Segurança utilizado em Relações Internacionais.

Over the past decade, the field of security studies has become one of the most dynamic and contested areas in International Relations. In particular, it has become perhaps the primary forum in which broadly social constructivist approaches have challenged traditional largely Realist and neorealist - theories on their "home turf", the area in which some of the most vibrant new approaches to the analysis of international politics are being developed, and the realm in which some of the most engaged theoretical debates are taking place. (WILLIAMS, 2003, p. 211)

A necessidade de que os, assim chamados, novos temas fossem levados em consideração influenciou a demanda por novas perspectivas teóricas, em segurança internacional. Essa denominação deve ser observada com cautela, pois o que ocorre não é, de fato, a emergência de novos temas que ameaçam a segurança internacional, pois esses já se faziam presentes no cenário internacional. O que ocorria era que tais temas não eram levados em consideração pelo paradigma predominante.

O que se faz a partir dessa temporalidade é perceber que assuntos, além dos tradicionais conflitos interestatais, como o exemplo da economia, poderiam afetar a segurança de um Estado. E, além disso, poderiam gerar um efeito "Spill Over"18 em outros países, afetando assim, essas demais economias.

O arrefecimento das tensões provocadas pela Guerra Fria e com ele a

Capacidade de transbordamento de problemas gerados por vulnerabilidades internas a países vizinhos que tenham problemas domésticos semelhantes. 
Artigo original

Hegemonia - Revista Eletrônica de Relações Internacionais do Centro Universitário Unieuro

ISSN: $1809-1261$

UNIEURO, Brasília, número 14, 2014, pp. 25-87.

alteração do padrão estabelecido, facilmente explicado pelas teorias existentes à época, incorreram no esvaziamento teórico, gerando a necessidade de uma teoria que explicasse o novo mundo que emergia.

Segundo Barry Buzan (1997), esse contexto tornou o campo de estudos em segurança mais atrativo. Nesse sentido, um dos aspectos que contribuiu para que isso acontecesse foi a fragmentação do debate em três "escolas": a vertente tradicionalista, a vertente crítica e a vertente abrangente. ${ }^{19}$

A vertente tradicionalista do debate em segurança internacional, consoante com as premissas realistas, preconiza a centralização da análise da segurança no aspecto militar, no uso da força e na visão estadocêntrica do mundo. Assim, somente Estados podem constituir ameaças exclusivas à segurança estatal (BUZAN, 1997; DUQUE, 2008; TANNO, 2003).

A vertente crítica, que, por sua vez, associa-se à perspectiva construtivista de matriz pós-moderna, defende uma posição de maior questionamento quanto à estrutura em que conceitua-se a segurança. Ao partir desse princípio, pressupõe-se que as ameaças à segurança sejam socialmente construídas, demonstrando certa intersubjetividade nessas construções, em relação a seu objeto referente. (BUZAN, 1997; DUQUE, 2008; TANNO, 2003)

A vertente abrangente, defendida pela Escola de Copenhague, advoga a ampliação da agenda de segurança, a fim de que, além de temas militares, sejam inseridos, também, temas não militares em sua análise. As ameaças não militares subclassificam-se conforme o setor a que pertencem, tais como o setor político, o setor econômico, o setor ambiental e o setor "societal". ${ }^{20}$

Termo que, neste trabalho, será substituído pelo vocábulo "vertente" para que não haja ambiguidade quanto à terminologia "Escola" utilizada para definir a Escola de Copenhague. Pelo fato de a Escola de Copenhague estar incorporada à vertente abrangente.

Cabe aqui mencionar que a adoção do vocábulo "societal" por parte dos autores é proposital para que seja diferenciado do termo "social". O primeiro refere-se à coletividade e sua identidade, já o segundo faz menção aos indivíduos e tem caráter econômico. 
Artigo original

Hegemonia - Revista Eletrônica de Relações Internacionais do Centro Universitário Unieuro

ISSN: $1809-1261$

UNIEURO, Brasília, número 14, 2014, pp. 25-87.

Trata-se de uma vertente intermediária ou alternativa, se comparada às outras duas. Essa posição deriva, principalmente, do fato de Duque (2009) caracterizar o papel de síntese da Escola de Copenhague. Convém observar que dois dos maiores expoentes dessa vertente apresentavam fundamentos construtivistas e realistas, antes de filiarem-se a essa Escola. Tal evento contribuiu para que nela se fundissem características das duas teorias. (BUZAN, 1997; DUQUE, 2009; TANNO, 2003)

Justamente por encontrar-se em posição intermediária, a Escola de Copenhague sofre críticas advindas de teóricos das duas outras vertentes. Mas as críticas sofridas pela Escola são o que levaram autores como Huysmans (1998b) e Tanno (2003) a descrever seu desenvolvimento como criativo. As críticas, segundo eles, motivaram revisões no trabalho e formulação de novas ideias.

\section{A Teoria da Securitização}

Os estudos teóricos produzidos na Escola de Copenhague desdobraramse na Teoria de Estado, no conceito de Análise Multissetorial da Segurança, no conceito de Complexos Regionais de Segurança e na Teoria da Securitização. Devido ao escopo limitado deste trabalho, analisar-se-á, unicamente, a Teoria da Securitização, que tem, em seu núcleo de concepção, os autores Barry Buzan e Ole Wæver.

O tema da segurança é tratado com especificidade técnica, no campo das Relações Internacionais. Nesse sentido, verifica-se que a segurança internacional não se confunde com temas, embora similares, afetos a campos 
Artigo original

Hegemonia - Revista Eletrônica de Relações Internacionais do Centro Universitário Unieuro

ISSN: $1809-1261$

UNIEURO, Brasília, número 14, 2014, pp. 25-87.

diversos de estudo. Esse é o caso da segurança pública, da segurança pessoal, da segurança nacional, da segurança doméstica, entre outros diversos campos de aplicação semântica do termo "segurança".

Barry Buzan e seus colaboradores começa o segundo capítulo de seu livro Security: A New Framework For Analysis (1998) com a seguinte pergunta: o que é segurança?". Para eles, a melhor forma de definir segurança, em termos internacionais, não é por meio de uma sentença rígida e imutável, mas, sim, em um contexto que tem seu início na percepção de uma determinada questão como ameaça à existência de um objeto referente.

Um exemplo tradicional, mas não único, de objeto referente é o próprio Estado. Nesse sentido, o tema da segurança internacional somente é percebido a partir do momento em que uma determinada questão passa a ser percebida, pela população de um determinado país, como uma ameaça à existência do Estado em que vive. Mais relevante que sua conceituação teórica é a identificação das consequências que a caracterização de uma ameaça implica.

A natureza distinta das ameaças à segurança justifica o uso de medidas extraordinárias para lidar com essa ameaça. Wæver salienta que "ao dizer 'segurança', o representante de um Estado declara uma situação de emergência, e, por conseguinte, reivindica o direito de utilizar quaisquer meios necessários para conter o desenvolvimento da ameaça". (Wæver 1998, 1995b apud Buzan et al, 1998; p.21).

Sendo assim, a segurança pode ser sintetizada como o movimento que leva um assunto para além das discussões políticas. Para Wæver, o uso dessa definição tem sido a maneira de legitimar o uso da força e, mais do que isso, tem possibilitado que Estados usem medidas especiais de força para lidar com ameaças a sua existência.

Assim como segurança, o conceito de ameaça e, com ele, o estabelecimento do que pode vir a ameaçar existencialmente um objeto referente, também é algo intersubjetivo. Validando tal análise, Buzan destaca que "ameaça só pode ser entendida em relação à característica particular do 
Artigo original

Hegemonia - Revista Eletrônica de Relações Internacionais do Centro Universitário Unieuro

ISSN: $1809-1261$

UNIEURO, Brasília, número 14, 2014, pp. 25-87.

objeto referente em questão." (1998; p. 22).

Nessa linha, Saint-Pierre (2011) destaca que a "ameaça não tem existência em si, senão que apenas se constitui e atua na percepção de quem é ou se sente ameaçado". Segundo ele, a ameaça diz respeito a uma interconexão entre a informação, seu emissor e o receptor. Em um ambiente em que esses três fatores podem variar, essa conectividade enseja a mutabilidade da percepção de ameaça, pelo receptor.

Saint-Pierre exemplifica seu argumento com a questão dos fluxos migratórios. Para os Estados Unidos da América, esse assunto é tido como uma das principais ameaças. Já para outros países do mundo, tal como o Brasil, o mesmo tema, em geral, não é avaliado com tamanha importância. Evidentemente, sempre que alguns temas, como a imigração haitiana voltam às discussões, a percepção de ameaça igualmente varia na percepção do brasileiro.

Rudzit e Nogami (2010) escrevem uma definição de Segurança Nacional que corrobora as duas afirmações acima expostas. Segundo eles, "a Segurança Nacional somente pode ser entendida como um problema político quando se tem ideia razoavelmente clara sobre a natureza de uma ameaça e as vulnerabilidades do objeto ao qual as ameaças são dirigidas".

Os autores incorporam um importante aspecto de análise a esse estudo, questão denominada vulnerabilidade. Nota-se que as ameaças, percebidas como riscos potenciais à existência de determinado objeto referente, têm foco direcionado a suas vulnerabilidades.

Ao constatar que sua existência foi colocada sob ameaça, os responsáveis pela defesa de um dado objeto referente podem, a fim de reduzir a insegurança percebida, concentrar-se na diminuição de suas vulnerabilidades ou, ainda, concentrar-se na contenção ou no enfraquecimento de suas ameaças potenciais.

Ao escolher enfraquecer suas ameaças, o Estado, como exemplo de objeto referente, não pode, simplesmente, declarar situação de emergência e 
Artigo original

Hegemonia - Revista Eletrônica de Relações Internacionais do Centro Universitário Unieuro

ISSN: $1809-1261$

UNIEURO, Brasília, número 14, 2014, pp. 25-87.

utilizar-se de todos os meios necessários para enfraquecer ou para conter suas ameaças potenciais. É necessário, antes disso, discutir-se o assunto no âmbito de seus espaços de política interna.

Buzan (et al, 1998) defende que, em teoria, qualquer assunto público pode constituir um ponto localizado em um espectro político que varia desde 0 assunto não politizado até o assunto securitizado, passando pelo assunto politizado. Quando um dado assunto localiza-se na zona não politizada do espectro, significa que tal matéria não constitui um tema de debate público, por parte do Estado. Quando, por outro lado, um tema configura-se um assunto politizado, significa que esse faz parte do debate político e que requer algum tipo de decisão governamental ou algum nível de alocação de recursos públicos.

Sem embargo, quando o assunto está na esfera dos assuntos securitizados, tal tema tem sido percebido como ameaça e, por isso, faz requererem-se medidas emergenciais, o que justifica a tomada de ações fora dos padrões normais do processo político. O que eleva um assunto de uma situação na qual o tema não é debatido à condição onde há debate público a respeito daquele tema é o processo de politização.

Assim como esse processo, o que leva um assunto ao status de securitizado é o movimento de securitização que, como já foi mencionado, passa pelo estabelecimento intersubjetivo da existência de uma ameaça com capacidade suficiente para causar efeitos políticos substanciais. (BUZAN et al, 1998, p. 25)

Para melhor compreensão do processo da securitização, faz-se necessária a apresentação dos conceitos que compõem sua estrutura.

- $\mathrm{O}$ ato-discurso (speech-act)

A conceituação de estado de exceção de Carl Schmitt coaduna-se com a teoria da securitização. Para ele, o estado de exceção caracteriza-se em situações atípicas e imprevisíveis capazes de gerar uma percepção de ameaça. São eventos que, geralmente, tendem a legitimar, em Estados liberais, a 
Artigo original

Hegemonia - Revista Eletrônica de Relações Internacionais do Centro Universitário Unieuro

ISSN: $1809-1261$

UNIEURO, Brasília, número 14, 2014, pp. 25-87.

utilização de medidas excepcionais.

[...]Estados liberais tendem a abandonar suas normas gerais pré-estabelecidas para justificar medidas excepcionais quando se percebem em face de eventos repentinos e normalmente imprevisíveis que, ao gerarem um sentimento de ameaça a sua própria existência, legitimam justificativas baseadas na não existência de tempo suficiente para reflexão e consideração (Bellamy et al., 2008 apud MOTTA, 2012, p.5)

Não obstante, Buzan (1998) alerta que a chave para estudar e entender a securitização é a análise do discurso, do ambiente político e de sua aceitação. Nesse sentido, cabe enfatizar que a securitização é um processo. Assim, para que aconteça, não basta apenas - como bem destacam os autores - proferir a palavra "segurança", desprovida de contexto fundamentador ou de legitimidade alguma.

Primeiramente, é necessária a existência de um discurso que apresente a ameaça a um público alvo. Em segundo lugar, o discurso tem que ser proferido por uma pessoa ou por entidade que detenha legitimidade sobre tal público alvo. É imprescindível, nesse sentido, agregar-se ao discurso o argumento de autoridade.

A partir desse ponto, considerando-se que a securitização se baseia na adoção de medidas excepcionais, torna-se válido questionar quando um argumento desse porte alcança dimensão suficiente para estimular a audiência a abandonar suas regras pré-estabelecidas e tolerar progressivas violações de regras que, em situações naturais, deveriam ser obedecidas.

Esse processo de convencimento de uma determinada audiência enseja a análise do chamado "speech-act" ou, como passaremos a utilizar, ato-discurso. Nesse sentido, Queiroz (2012), ao tratar a construção do ato-discurso, utiliza-se da Teoria dos Atos da Fala e de conceitos semânticos, tais como o de ato locucionário, o de ato ilocucionário e o de ato perlocucionário. 
Artigo original

Hegemonia - Revista Eletrônica de Relações Internacionais do Centro Universitário Unieuro

ISSN: $1809-1261$

UNIEURO, Brasília, número 14, 2014, pp. 25-87.

De acordo com a categorização dos atos da fala tal qual elaborada por AUSTIN (1990), o ato locucionário seria "o que se diz", ou seja, a utilização de signos linguísticos (sons e palavras) com significado; o ato ilocucionário seria "o como se diz", o ato em si, praticado ao se enunciar determinada oração em uma dada circunstância e com uma finalidade. Por fim, os atos perlocucionários seriam os efeitos decorrentes da ação de se dizer algo. Ressaltese, ainda, que esta tipologia é uma abstração teórica já que $o$ ato linguístico deve ser considerado como um todo (QUEIROZ, 2012, p.67).

Faz-se necessária a observação holística e abrangente do discurso, que não deve ser analisado isoladamente, como se fosse um jogo de cartas entre amadores, no qual apenas observa-se a possibilidade de um discurso ser ou não ser um blefe, naquela rodada. Trata-se, na verdade, de perceber o discurso como parte de um contexto específico, em que se conectam o discurso e a possibilidade de que essa interação produza efeitos concretos.

O discurso que apresenta determinado tema como ameaça à existência daquele objeto referente não caracteriza, por si só, a securitização do correspondente tema. Faz-se necessária a aquiescência e a aceitação do público-alvo. Se não houver aceitação, pode-se apenas falar em um movimento de securitização e não de uma securitização, propriamente dita. A securitização é o último passo desse processo.

Pode-se, por via de consequência, estabelecer que a securitização de um tema é algo negociado entre o agente securitizador e sua audiência, onde o primeiro precisa formar, na segunda, convencimento sobre os três aspectos seguintes: i) que, por meios tradicionais, não há como conter com a ameaça apresentada; ii) que, se não for tomada uma atitude imediatamente, poderá ser tarde demais; iii) que a inércia poderá resultar um efeito irreversível. Para que haja o convencimento, o agente securitizador precisa demonstrar e comprovar, perante a audiência, o caráter iminente da ameaça e o caráter prioritário da 
Artigo original

Hegemonia - Revista Eletrônica de Relações Internacionais do Centro Universitário Unieuro

ISSN: $1809-1261$

UNIEURO, Brasília, número 14, 2014, pp. 25-87.

ação, associando-a à sobrevivência do objeto referente (BUZAN et al, 1998, p. 26).

- Unidades de análise em segurança internacional

Para Buzan e para seus colaboradores, a análise da segurança internacional requer que se faça distinção entre três tipos de unidades constituintes da abordagem do ato-discurso, a saber: a) o objeto referente; b) o ator securitizador; e c) o ator funcional. (BUZAN et al, 1998, p. 35).

O objeto referente é constituído por tudo aquilo que possa ser percebido como passível de sofrer uma ameaça à sua existência e que, ao mesmo tempo, detenha legitimidade para alegar a imperiosidade de sua sobrevivência. Tradicionalmente, até os movimentos de ampliação do conceito de segurança, essa definição pertenceu ao Estado. A isso equivale dizer que o Estado, tradicionalmente, era caracterizado como sendo o objeto referente por definição. Disso derivava concluir que: i) a existência do Estado era passível de ser entendida como ameaçada; e ii) o Estado possuía, como ainda possui, legitimidade para clamar a imperiosidade de sua existência.

Quanto ao objeto referente, tem-se que este é o ente em favor do qual o movimento de securitização será feito. É quem sofre a ação ou encontra-se ameaçado de sofrê-la. Os atores securitizadores percebem a existência de um risco potencial existência do objeto referente e fazem o público alvo, ao ouvir o discurso, decidir que somente a adoção de medidas extraordinárias poderão garantir a sobrevivência de tal referente.

Após a ampliação dos estudos sobre segurança internacional, bem como a natureza cada vez menos estado-centrista dos estudos de Relações Internacionais, ensejaram um aumento na quantidade de unidades passíveis de serem declaradas objetos referentes, isto é, objetos sujeitos à análise e à validação do público alvo. Não obstante, o Estado continua a ser o principal objeto referente nas análises da securitização.

O ator securitizador é um indivíduo ou um grupo de indivíduos apto a 
Artigo original

Hegemonia - Revista Eletrônica de Relações Internacionais do Centro Universitário Unieuro

ISSN: $1809-1261$

UNIEURO, Brasília, número 14, 2014, pp. 25-87.

proferir um discurso conforme o qual determinado assunto apareça como ameaça à existência de um objeto referente, a ponto tal que se configure a emergência da adoção de medidas extraordinárias. Ademais, constitui-se condição sine qua non a percepção de que esse indivíduo ou seu conjunto, o ator securitizador, possua uma posição de legitimidade em face do público alvo.

Embora tenha relevância no processo de securitização, o ator funcional, por exclusão, não pode ser confundido com o objeto referente, pois não é passível de ameaça, tampouco pode confundir-se com o ator securitizador, pois não é o portador do ato-discurso. Trata-se daquele ator que, não obstante, exerce, também, algum tipo de influência ou de interesse sobre o processo ou, ainda, pode ser afetado por ele.

Ao juntar o conceito de ato-discurso às unidades de análise em segurança, pode-se chegar à seguinte conclusão: o ator securitizador tanto pode ser um indivíduo dentro de um Estado quanto um grupo que esteja em posição de legitimidade. Do contrário, ao pronunciar-se na tentativa de apresentar a ameaça ao seu público-alvo, desprovido de credibilidade, o indivíduo veria o seu discurso não ser recepcionado pela audiência. Certo é que a não aceitação impede configurar-se a securitização do tema, constituindo, antes, apenas um simples movimento de securitização.

Os atores funcionais devem ser entendidos como aqueles que possuem o poder de afetar a dinâmica de um setor específico da sociedade. Por exemplo, colocando em termos práticos, em um caso de invasão, onde a segurança do Estado "A" foi ameaçada pelo Estado "B". Nessa situação, o Estado "A" é o objeto referente. O presidente do Estado "A" (ator securitizador) faz um pronunciamento (ato-discurso) à nação argumentando que a integridade e a segurança do seu país está sendo ameaçada e que é necessária a adoção de uma medida imediata para conter tal ameaça (ato ilocucionário). O consentimento da sua população (público-alvo) e aceitação caracterizam a securitização do tema - invasão de seu território pelo Estado "B".

Nessa situação hipotética, um possível ator funcional seria uma empresa 
Artigo original

Hegemonia - Revista Eletrônica de Relações Internacionais do Centro Universitário Unieuro

ISSN: $1809-1261$

UNIEURO, Brasília, número 14, 2014, pp. 25-87.

que fornece armamentos ao Estado "A". Tal empresa não está sendo ameaçada pela invasão de "B", e, muito menos, tem legitimidade necessária para se pronunciar à população de "A" para convencê-los da ameaça iminente; entretanto, tem influência suficiente para afetar a dinâmica da ação de contenção da ameaça.

Se considerasse-se que o único fornecedor de armamentos do país " $A$ " seja uma empresa estatal do país " $B$ ", que também fornecesse armamento para o seu próprio país, não é difícil supor que essa empresa, em primeiro plano, cancelaria o fornecimento de armamentos para o país " $A$ ". Diante da sua relevância no processo de securitização, essa empresa poderia ser compreendida como um ator funcional. O que levaria, em tal situação, o país "A" a não possuir armamentos e munição suficientes para conter o avanço do país "B" sobre seu território.

Com essa situação, pode-se visualizar a dinâmica da securitização sendo afetada por um ente que não se configura como objeto referente e, muito menos, como ator securitizador; mas, não obstante, com capacidade suficiente para influenciar todo o processo, impedindo que um ato ilocucionário se transforme em um ato perlocucionário.

Em suma, um processo de securitização bem sucedido passa por três passos: a) identificação de ameaças como risco à existência de um objeto referente; b) a adoção de ações emergenciais em caráter extraordinário; e, c) os efeitos concretos causados pela quebra de regras que, em outras situações, teriam que ser obedecidas. (BUZAN et al, 1998, p. 26).

\section{A TEORIA DA SECURITIZAÇÃO E A GUERRA DO AFEGANISTÃO}

Como já mencionado, o objetivo central deste estudo é verificar a validade empírica da Teoria da Securitização, defendida por Barry Buzan e Ole 
Artigo original

Hegemonia - Revista Eletrônica de Relações Internacionais do Centro Universitário Unieuro

ISSN: $1809-1261$

UNIEURO, Brasília, número 14, 2014, pp. 25-87.

Wæver. Para esse fim, far-se-á um estudo de caso da Guerra do Afeganistão a partir das lentes dessa teoria.

Nesta sessão do estudo, serão analisados os elementos que constituem o processo de securitização de um determinado tema - conforme foram definidos na primeira sessão deste estudo. Posteriormente, tais elementos serão confrontados com os eventos que ocorreram desde os momentos imediatamente posteriores aos ataques do dia 11 de setembro de 2001 até a incursão militar norte-americana no Afeganistão - conforme foram narrados na segunda sessão do presente estudo.

Finalmente, serão observados os discursos proferidos por aqueles que serão, neste trabalho, caracterizados como atores securitizadores, analisandose todo o processo mediante o qual o tema do terrorismo foi elevado ao nível de política de pânico, justificando, por conseguinte, a tomada de medidas ditas necessárias para a contenção da ameaça percebida.

A Securitização do terrorismo

O primeiro passo da análise do processo de securitização de um determinado tema, por um objeto referente, é a definição do que este objeto referente percebe como ameaça. Tal como mencionou-se no capítulo anterior, o conceito de ameaça varia conforme a percepção de cada objeto referente. Não há um conceito universal de ameaça, pois é ela moldada de acordo com o contexto e com a percepção única de cada objeto referente (SAINT-PIERRE, 2011).

No caso dos Estados Unidos da América, a ameaça restou evidente. A ousadia dos terroristas, ao realizar um ataque, em território norte-americano, contra um símbolo da arquitetura norte americana, matando milhares de pessoas, além da ampla cobertura produzida pelas grandes emissoras de 
Artigo original

Hegemonia - Revista Eletrônica de Relações Internacionais do Centro Universitário Unieuro

ISSN: $1809-1261$

UNIEURO, Brasília, número 14, 2014, pp. 25-87.

televisão, disseminou o medo em toda a nação. A carência de informações ou, melhor ainda, a lentidão com que as explicações foram sendo apresentadas ao público gerou dúvidas sobre o caráter final do ataque às torres gêmeas. $O$ medo de que mais ataques acontecessem espalhou-se rapidamente e amplamente.

O objeto referente de tais ataques, observados neste estudo, foram o Estado norte-americano. Não somente a instituição estatal, mas os elementos que a compõem: o sentimento de nacionalidade norte-americana (american way of life), a integridade de território e a eficiência de seu governo soberano. O país passara por outros ataques terroristas, como os que ocorreram na Tanzânia e no Quênia em 1998.

Sem embargo, os ataques de 11 de setembro de 2001 foram os primeiros perpetrados em seu território. Foram, igualmente, os primeiros a repercutirem tão amplamente na imprensa. Em 1993, o World Trade Center havia sido alvo de ataques terroristas, mas, naquela vez, uma bomba explodiu no subsolo do prédio, matando 6 pessoas - número considerado baixo, se comparado ao que se verificou em 2001.

O Presidente Bush, em discurso proferido imediatamente após os ataques, argumentou que, não somente a nação e o território norte-americanos, mas, também, a liberdade e o modo de vida estadunidense tiveram sua existência ameaçada em razão dos ataques às torres gêmeas de Nova Iorque (BUSH, 2001).

Tendo em vista que a ameaça somente pode ser detectada a partir da percepção do objeto referente, pode-se concluir que se faz necessário, em primeiro lugar de uma análise, a identificação do objeto referente para que, a partir dela, seja visualizada a ameaça segundo sua percepção. Assim, deve-se destacar o modo de vida norte-americano e a sua liberdade - dentro do espectro maior que seriam seu território e sua nação - como sendo os objetos referentes ameaçados e o terrorismo como ameaça a tais.

Feita essa identificação inicial da ameaça e dos objetos referentes, 
Artigo original

Hegemonia - Revista Eletrônica de Relações Internacionais do Centro Universitário Unieuro

ISSN: $1809-1261$

UNIEURO, Brasília, número 14, 2014, pp. 25-87.

seguimos a identificar o ator securitizador, isto é, o ente detentor de legitimidade para elevar um tema do status de politizado ao nível de securitizado. Para identificar-se o ator securitizador, cabe uma análise dos demais atores que compunham o processo decisório na cúpula do governo dos Estados Unidos da América, na época. A imagem abaixo identifica tais atores e seus cargos.

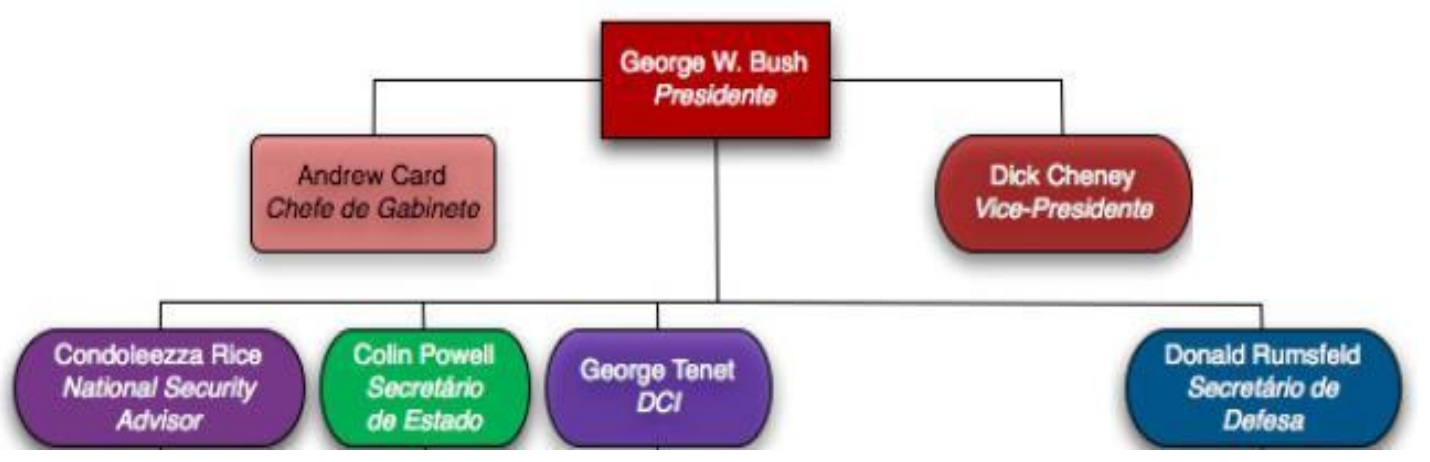

Imagem 1: Organograma do processo decisório em Segurança Nacional (20012003)

Fonte: Elaborado pelos autores, a partir de DUQUE, 2008

Como já discutiu-se, neste trabalho, o ator securitizador, segundo Buzan, é um determinado indivíduo ou grupo que possua legitimidade frente ao público alvo. Conforme depreende-se do organograma acima, confeccionado a partir de dados fornecidos por Duque (2008), o Presidente George W. Buch, na posição de Chefe de Estado e de Chefe de Governo, na época, constituía a autoridade máxima do decisório norte-americano, inclusive no que concerne à Segurança Nacional.

Ainda que esteja laureado de auxiliares, de assistentes e de assessores e que receba informações de instâncias inferiores, como do Vice-Presidente da República, do Chefe de Gabinete, da Conselheiro de Segurança Nacional (National Security Advisor) e dos Secretários de Defesa e Estado, qualquer decisão a ser tomada recai sobre a responsabilidade do Presidente da República. Bem assim, sobre ele repousa a responsabilidade de pronunciar-se, em relação 
Artigo original

Hegemonia - Revista Eletrônica de Relações Internacionais do Centro Universitário Unieuro

ISSN: $1809-1261$

UNIEURO, Brasília, número 14, 2014, pp. 25-87.

ao tema, perante a nação. Logo, não é difícil concluir que o Presidente George W. Bush, no contexto das unidades de análise da Teoria da Securitização, é o ator securitizador, no caso dos eventos que se seguiram aos ataques de 11 de setembro de 2001, inclusive a Guerra do Afeganistão.

De mais a mais, deve-se salientar que o processo de securitização passa pela necessidade de convencimento de um determinado público alvo, por parte do ator securitizador. Impende, nesse sentido, indagar quem foi o público alvo, no caso da Guerra do Afeganistão de 2001 ou, ainda mais, qual seriam os atores internos que precisariam ser convencidos da iminência das ameaças e da pertinência da tomada de medidas extraordinárias, a fim de que o tema fosse, ao final, securitizado.

Um primeiro público alvo seria o próprio povo norte-americano; a opinião pública norte-americana, portanto, seria a primeira destinatária do discurso. Essa seria, em tese, mais fácil de convencer pelo impacto dos ataques no senso geral de comoção nacional.

Há algumas condições que contribuem com o sucesso de determinado processo de securitização, tais como a legitimidade e a credibilidade do ator securitizador, além das características inerentes à ameaça por ele apresentada (Buzan, 1998). Ainda assim, em uma democracia como os Estados Unidos, é necessário o convencimento e a aprovação dos representantes do povo. Podemos verificar a forma dupla de público alvo, nesse caso particular, a partir do pronunciamento do Presidente Bush ao Congresso em 20 de setembro.

Mr. Speaker, Mr. President Pro Tempore, members of Congress, and fellow Americans: In the normal course of events, Presidents come to this chamber to report on the state of the Union. Tonight, no such report is needed. It has already been delivered by the American people. (BUSH, 2001, p. 65)

O povo norte-americano, como a ele refere-se, no texto, estava extremamente amedrontado e já, por consequente, esperava que alguma 
Artigo original

Hegemonia - Revista Eletrônica de Relações Internacionais do Centro Universitário Unieuro

ISSN: 1809-1261

UNIEURO, Brasília, número 14, 2014, pp. 25-87.

atitude fosse tomada pelo Presidente da República. Sob tais circunstancias, a dificuldade de convencimento da população, com relação à ameaça terrorista, era relativamente pequena (RICE, 2011).

O Congresso norte-americano, por sua vez, mesmo que já se houvesse manifestado a favor da população, liberando um orçamento de US\$ 40 bilhões para a reconstrução das comunidades afetadas e para o orçamento militar, ainda precisava ser formalmente consultado relativamente a qualquer tentativa de securitização feita pelo Presidente (BUSH, 2001).

A lógica do Speech Act no caso da Guerra do Afeganistão

Como mencionou-se, na primeira sessão deste trabalho, a securitização de um tema é um processo que atravessa algumas etapas (BUZAN,1998). Nesse sentido, o público alvo é conduzido a levar o tema às seguintes e sucessivas categorias: não-politizado, politizado, securitizado.

Definem-se não-politizados os temas que não são discutidos amplamente na esfera política. Os assuntos politizados, por conseguinte, são aqueles que são percebidos como temas passíveis de discussões políticas e de deliberações. Os assuntos securitizado são aqueles alçados à categoria de relevância superior à política, por causa do que podem-se utilizar todas as medidas necessárias para a contenção da ameaça nele identificada (BUZAN, 1998).

Para uma melhor compreensão, ilustram-se, na imagem abaixo, os caminhos que levam um tema do estamento não-politizado ao nível de securitização, no topo do processo.

MOVIMENTO DE SECURITIZAÇÃO 
Artigo original

Hegemonia - Revista Eletrônica de Relações Internacionais do Centro Universitário Unieuro

ISSN: 1809-1261

UNIEURO, Brasília, número 14, 2014, pp. 25-87.

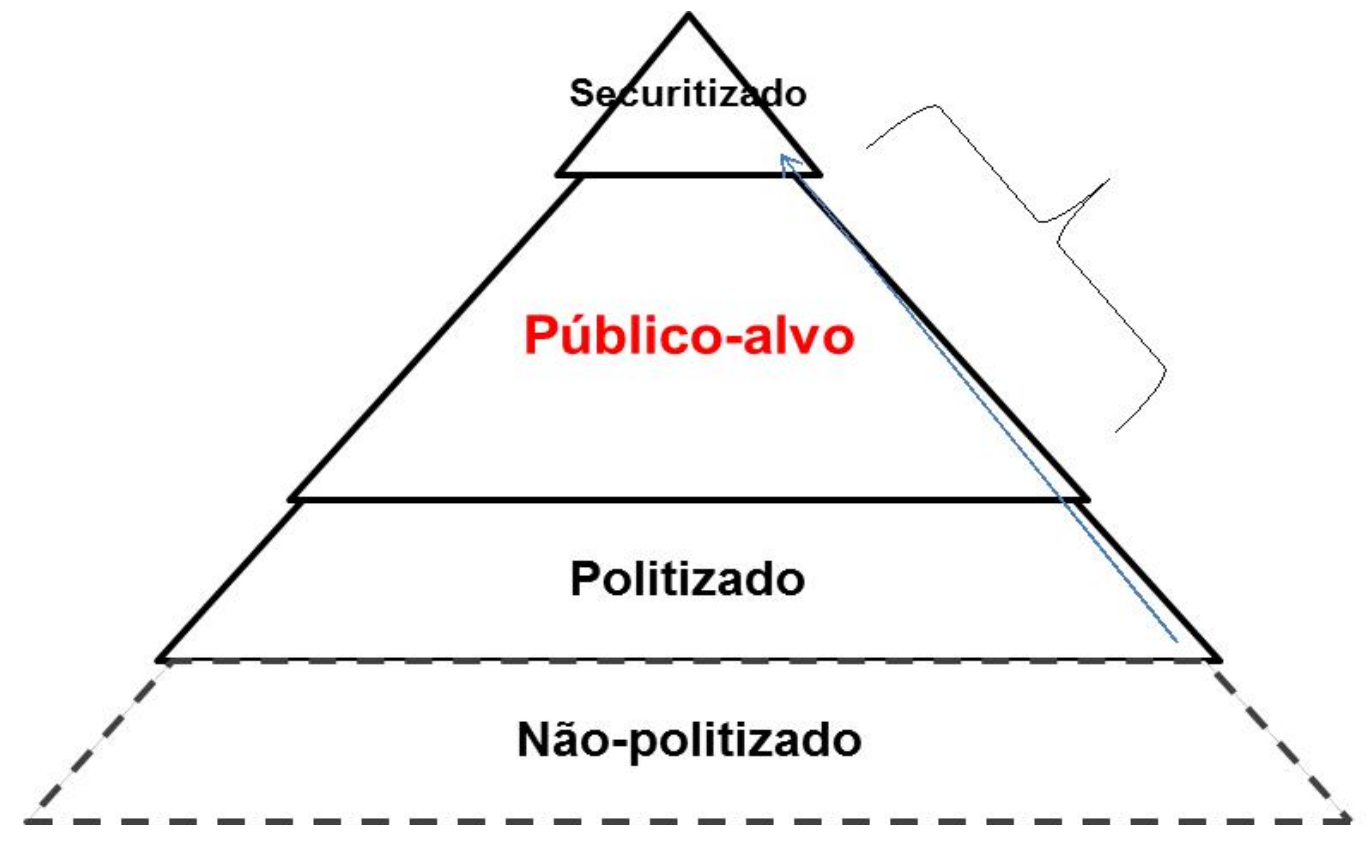

Imagem 2: Níveis de importância de determinado tema no âmbito da tomada de decisão

Fonte: Elaborado pelos autores, com base em Cardoso (2013).

Conforme verifica-se, na figura acima, o processo de securitização de determinado tema somente completa-se mediante o convencimento do público alvo. Se um tema for apresentado, pelo ator securitiador, como passível de ser tratado, exclusivamente, mediante a adoção de medidas extraordinárias, mas o público alvo não aderir a tal discurso, o tema não é securitizado. A adesão do público alvo é feita com base nos discursos proferidos pelo ator securitizador (BUZAN, 1998).

Tomando-se em linha de conta que o objetivo do presente estudo é validar a aplicabilidade da Teoria da Securitização ao caso da Guerra do Afeganistão, torna-se imprescindível realizar-se a análise dos discursos feitos pelo Presidente Bush. Assim, investigar-se-á a possibilidade de identificá-lo como ator securitizador do tema, na lógica da tentativa de convencimento do público alvo, da opinião pública e do Congresso norte-americano, sobre a necessidade de elevar-se o tema do terrorismo a um patamar emergencial, acima das práticas ordinárias da política interna. 
Artigo original

Hegemonia - Revista Eletrônica de Relações Internacionais do Centro Universitário Unieuro

ISSN: $1809-1261$

UNIEURO, Brasília, número 14, 2014, pp. 25-87.

Nesse sentido, verifica-se que o primeiro pronunciamento do Presidente George W. Bush foi feito ainda no dia 11 de setembro de 2001, logo após os ataques. A rapidez com que reagiu o presidente foi interpretada como um sinal da urgência do assunto e, por consequência, constituiu importante elemento favorável à securitização do tema.

Em seu discurso, como espera-se de um Chefe de Estado, o Presidente disse que estava em luto pelos que perderam suas vidas durante os ataques e que os Estados Unidos ficariam bem pois é um país forte. Entretanto, ao se tratar dos terroristas, teve um tom direto e firme. (RICE, 2011)

Today, our fellow citizens, our way of life our very freedom came under attack in a series of deliberate and deadly terrorists attacks. [...] Thousands of lives were suddently ended by evil, despicable acts of terror. [...] These acts of mass murder were intended to frighten our nation into chaos and retreat. But they have failed; our country is strong. [...] The search is underway for those who are behind this evil acts. I've redirected full resources of our intelligence and law enforcementommunities to find those responsible and bring them to justice. We will make no distinction between the terrorists who committed these acts and those who harbor them. (BUSH, 2001, p. 58)

Antes do pronunciamento, o Presidente questionou sua Conselheira de Segurança Internacional, Condoleezza Rice, a respeito da necessidade de incluir-se, no pronunciamento, a última sentença do fragmento de texto acima: "Nós não faremos distinção entre os terroristas que cometeram esses atos e aqueloutros que o apoiaram". Ela respondeu-lhe que "achava que ele deveria dizê-la na primeira mensagem porque depois perderia o impacto" (RICE, 2011).

A importância dessa sentença, no primeiro pronunciamento, pode ser observada à luz do ato ilocucionário, já conceituado no capítulo anterior. $\mathrm{O}$ ato ilocucionário está relacionado à forma como se faz um pronunciamento. Nele, 
Artigo original

Hegemonia - Revista Eletrônica de Relações Internacionais do Centro Universitário Unieuro

ISSN: $1809-1261$

UNIEURO, Brasília, número 14, 2014, pp. 25-87.

as palavras de um discurso estão fundamentadas em um contexto específico e, se fossem ditas em outro tempo ou em outro contexto, não teriam o mesmo impacto (QUEIROZ, 2012).

O contexto que está por trás da sentença dita pelo Presidente dos Estados Unidos constitui os próprios ataques terroristas perpetrados naquele mesmo dia, quando população esperava um posicionamento enfático e uma solução eloquente para aquela situação. A perspicácia da alocação do discurso em um contexto adequado, utilizado para os fins desejados pelo seu anunciante, foi tão bem sucedida que, algum tempo depois, veio a ser apresentada (RICE, 2011) como um dos elementos mais importantes discursos da Doutrina Bush. ${ }^{21}$

Outro aspecto que cabe ressaltar, a respeito da lógica do ato ilocucionário aplicado à guerra, foi o fato de que, no primeiro discurso à nação, o Presidente, prontamente, pela primeira vez, declara guerra ao terrorismo, juntamente com seus "amigos e aliados", e mostra-se favorável a aliar-se a quem desejasse paz e segurança, no mundo. (BUSH, 2001)

Faz-se necessário mencionar que esses discursos iniciais tem duas finalidades. A primeira, que já foi levantada nesse estudo e a razão pela qual os estamos analisando, é o convencimento do público interno. A segunda, é passar uma mensagem aos responsáveis pelos ataques, até então desconhecidos, de que os Estados Unidos iriam responder aos ataques de forma incisiva. (RICE, 2011)

Três dias depois dos ataques, o Presidente, em discurso proferido na National Cathedral, continuou a condenar os ataques, expressando suas condolências às famílias que haviam perdido seus parentes, nos ataques,

Estratégia de política externa contra o terrorismo do governo Bush que introduziu o uso de força militar em operações de contenção do terrorismo, reforçando as percepções de estado de guerra. 
Artigo original

Hegemonia - Revista Eletrônica de Relações Internacionais do Centro Universitário Unieuro

ISSN: $1809-1261$

UNIEURO, Brasília, número 14, 2014, pp. 25-87.

enfatizando que respostas seriam adotadas a fim de perseguir e punir os responsáveis.

[...] our responsibility to history is already clear: to answer these attacks and rid the world of evil. [...] This nation is peaceful, but fierce when stirred to anger. This conflict was begun on timing and terms of others. It will end in a way, and at an hour of our choosing. (BUSH, 2001, p. 59)

Durante os dias subsequentes aos ataques, o Presidente, em todos os seus pronunciamentos, referiu-se à adoção de medidas para a contenção da ameaça terrorista ou para a oferta uma resposta aos ataques.

Para Buzan et al (1998), a retórica encontradiça nos discursos de securitização proferidos pelo ator securitizador é bem clara. É nítido o propósito de convencimento de seu público alvo. Para alcançar seu fim, o ator não faz referência apenas à sobrevivência da unidade, mas refere-se, semelhantemente, à necessidade da adoção de medidas emergenciais de contenção da ameaça erigida contra o objeto referente (DUQUE, 2008).

Antes de discutir-se os efeitos da securitização, no caso sob comento, convém evocar a conceituação de securitização, conforme expendida por Buzan. Para ele, securitização é "the move that takes politics beyond the established rules of the game and frames the issue either as special kind of politics or as above politics" (BUZAN et al, 1998, p.23); portanto securitização, segundo ele, é o movimento que eleva determinado assunto a um nível tal que se permita a adoção de políticas emergenciais extraordinárias.

Ainda no dia 14 de setembro de 2001, dia do pronunciamento proferido pelo Presidente na National Cathedral, tomou-se a primeira ação emergencial, com relação ao terrorismo. Nesse dia, o Congresso norte-americano aprovou a denominada Senate Joint Resolution 23, que autorizava o Presidente a usar toda a força necessária e apropriada contra aquelas nações, organizações ou indivíduos que, segundo o seu julgamento, tivessem planejado, autorizado, cometido ou ajudado a realização dos ataques terroristas de 11 de setembro, 
Artigo original

Hegemonia - Revista Eletrônica de Relações Internacionais do Centro Universitário Unieuro

ISSN: $1809-1261$

UNIEURO, Brasília, número 14, 2014, pp. 25-87.

ainda que, simplesmente, tivessem-se limitado a abrigar tais organizações ou pessoas.

Como bem aponta Duque (2008), apenas três dias após os ataques, o Poder Legislativo norte-americano, por meio dessa resolução, a Resolução no 23 , concedeu uma espécie de carta branca ao Poder Executivo, para deliberar sobre que rumo as ações, em resposta às agressões, deveriam tomar. A respeito dessa resolução, Daaler e Lindsay (2003, p. 90) afirmaram que "in effect, Congress declared war and left it up to the White House to decide who the enemy was."

A Resolução no 23 é o primeiro sinal nítido de que o tema do terrorismo foi retirado da esfera de politizado e alçado ao nível de assunto securitizado, conforme o organograma apresentado anteriormente, neste estudo. Mesmo que esse tema, em si, ainda não estivesse totalmente securitizado, a consolidação desse fato já sinalizava nessa direção.

Uma das formas de medir a aprovação do governo Bush, durante o período imediatamente após os ataques de 11 de setembro de 2011, e de verificar a aceitação dos discursos por parte do público alvo é a análise dos índices de aprovação do Presidente, publicados naquela época.

Segundo Duque (2008), com sua reação aos ataques, a taxa de aprovação Presidencial subiu de $51 \%$ (cinquenta e um por cento), conforme mediu-se no período de 7 a 10 de setembro, para a impressionante marca de $90 \%$ (noventa por cento), conforme verificado entre os dias 21 e 22 de setembro daquele ano. Convém ressaltar que esse foi o mais alto nível de popularidade presidencial já medido na história dos Estados Unidos da América.

Após esse momento, conforme verifica-se no gráfico abaixo, a taxa de aprovação do Presidente George W. Bush adota a tendência de queda até o ano de sua saída do cargo. A figura abaixo ilustra a constatação de Duque. 
Artigo original

Hegemonia - Revista Eletrônica de Relações Internacionais do Centro Universitário Unieuro

ISSN: $1809-1261$

UNIEURO, Brasília, número 14, 2014, pp. 25-87.

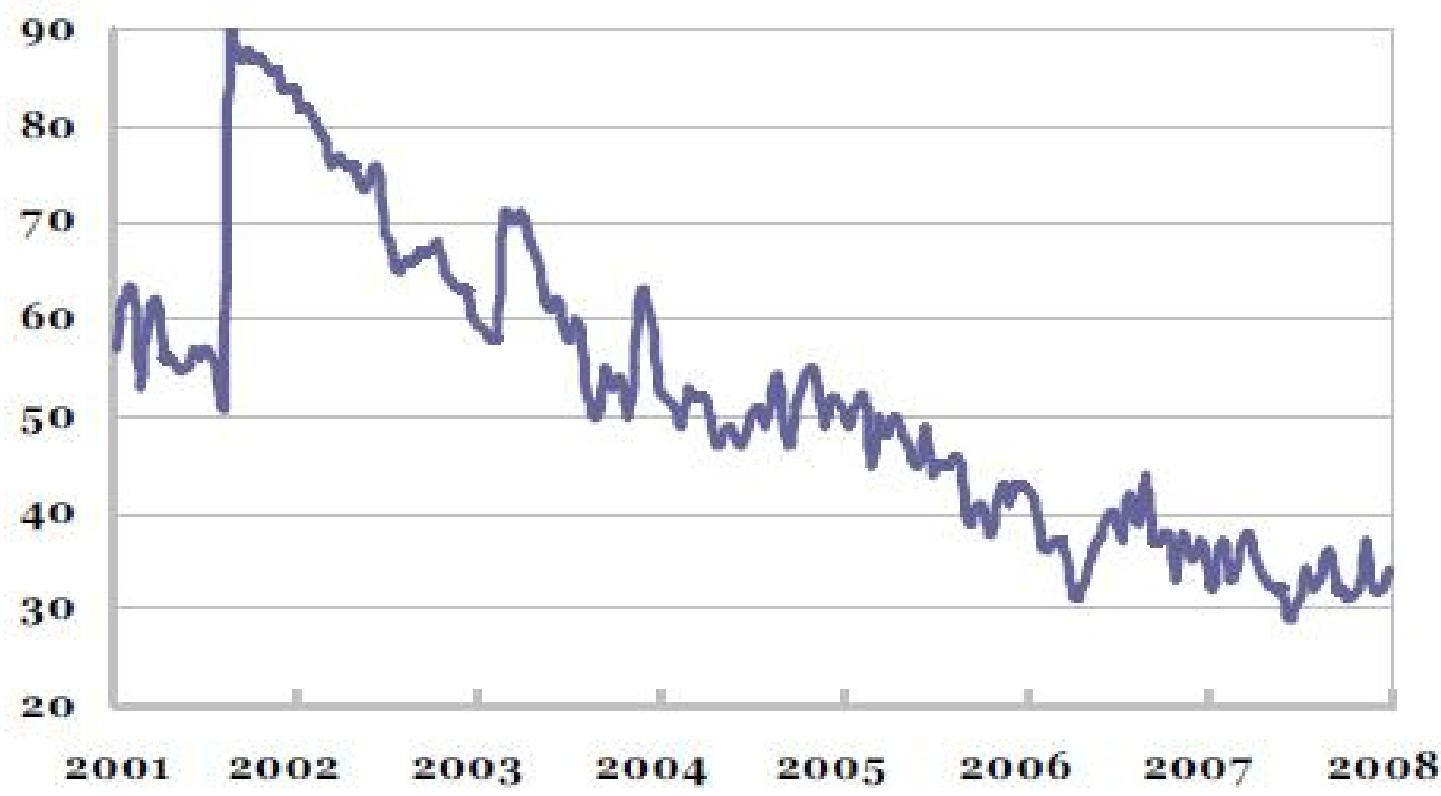

Figura 3. Taxa de aprovação do Presidente George W. Bush na presidencia, 2001-08 (\%)

Fonte: Duque, 2008, p. 14.

Tanto a aprovação da Senate J oint Resolution 23 quanto o aumento da taxa de aprovação presidencial são instrumentos de análise que evidenciam o alto grau de convencimento do público norte-americano quanto à potencialidade lesiva da ameaça terrorista contra a sobrevivência do objeto referente. Essa premissa leva à conclusão de que foi bem sucedido o movimento político que levou o tema do terrorismo ao nível de securitização.

Com a permissão dada pelo Congresso e com o apoio da população, o Presidente George W. Bush aumentou o tom de seus discursos e começou a sinalizar o início da guerra contra o terrorismo.

Em 20 de setembro de 2001, em seu discurso proferido no Congresso, o Presidente nomeou o responsável pelos ataques e fez uma série de demandas à al Qaeda e ao Afeganistão.

[...] And tonight, the United States of America makes the following demands on the Taliban: Deliver to United 
Artigo original

Hegemonia - Revista Eletrônica de Relações Internacionais do Centro Universitário Unieuro

ISSN: 1809-1261

UNIEURO, Brasília, número 14, 2014, pp. 25-87.

States' authorities all the leaders of al Qaeda who hide in your land. Release all foreign nationals, including American citizens, you have unjustly imprisoned. Protect foreign journalists, diplomats and aid workers in your country. Close immediately and permanently every terrorist training camp in Afghanistan, and hand over every terrorist, and every person in their [sic] support structure, to appropriate authorities. Give the United States full access to terrorist training camps, so we can make sure they are no longer operating. These demands are not open to negotiation or discussion. The Taliban must act, and act immediately. They will hand over the terrorists, or they will share in their fate (BUSH, 2001, p. $67)$.

Pela lógica do ato ilocucionário, que usamos há pouco para analisar o primeiro discurso, verifica-se que esse pronunciamento, realizado no dia 20 , ganhou mais peso. Além do fato de possuir um plano de fundo ou um contexto que o validava a dizer tais coisas, o fato de estar respaldado na aceitação da opinião pública intensificou, ainda mais, seu discurso e tornou o discurso muito mais susceptível de gerar implicações práticas - tornando-se um ato perlocucionário.

No mesmo discurso, o Presidente afirmou:

Our war on terror begins with al Qaeda, but it does not end there. It will not end until every terrorist group of global reach has been found, stopped and defeated. [...] Americans are asking: How will we fight and win this war? We will direct every resource at our command - every means of diplomacy, every tool of intelligence, every instrument of law enforcement, every financial influence, and every necessary weapon of war - to the disruption and to the defeat of the global terror network (BUSH, 
Artigo original

Hegemonia - Revista Eletrônica de Relações Internacionais do Centro Universitário Unieuro

ISSN: $1809-1261$

UNIEURO, Brasília, número 14, 2014, pp. 25-87.

$$
\text { 2001, p. 68). }
$$

Aqui se torna nítida a promessa de adoção de medidas emergenciais, acima das medidas de política usuais, para a contenção da ameaça. Quando o ator securitizador chega a pronunciar-se dessa forma, com o respaldo da opinião pública, a etapa do movimento de securitização ilustrada na imagem 2 já foi concluída. Fica restando, tão somente, a consolidação dos atos.

Conforme explicou-se anteriormente, esse discurso ainda tem a forma de um discurso ilocucionário, ou seja, não possui implicações práticas, mas apenas promessas. A promessa de que, se não forem atendidas as demandas enumeradas pelo Presidente dos Estados Unidos da América, medidas emergenciais haveriam de ser adotadas.

Our response involves far more than instant retaliation and isolated strikes. Americans should not expect one battle, but a lengthy campaign, unlike any other we have ever seen. It may include dramatic strikes, visible on TV, and covert operations, secret even in success. We will starve terrorists of funding, turn them one against another, drive them from place to place, until there is no refuge or no rest. And we will pursue nations that provide aid or safe haven to terrorism. Every nation, in every region, now has a decision to make. Either you are with us, or you are with the terrorists. From this day forward, any nation that continues to harbor or support terrorism will be regarded by the United States as a hostile regime (BUSH, 2001, p. 68).

Em 7 de outubro do mesmo ano, logo, menos de um mês após os ataques terroristas, iniciaram-se as ofensivas norte-americanas. Em pronunciamento, o Presidente publicitou o início das incursões militares e seus objetivos operacionais, a saber, a destruição de campos de treinamento de terroristas, no Afeganistão, e destruição da capacidade militar do regime talibão: 
Artigo original

Hegemonia - Revista Eletrônica de Relações Internacionais do Centro Universitário Unieuro

ISSN: $1809-1261$

UNIEURO, Brasília, número 14, 2014, pp. 25-87.

On my orders, the United States military has begun strikes against al Qaeda terrorist training camps and military installations of the Taliban regime in Afghanistan. These carefully targeted actions are designed to disrupt the use of Afghanistan as a terrorist base of operations, and to attack the military capability of the Taliban regime (BUSH, 2001, p.75).

O presidente reportou-se ao discurso anterior para justificar os ataques. Segundo dispôs, os ataques derivavam da recusa, por parte dos representantes do regime talibão, de cumprir as exigências feitas pelos Estados Unidos da América, isto é, a completa e irrestrita submissão militar ao seu país. Segue um fragmento do texto:

More than two weeks ago, I gave Taliban leaders a series of clear and specific demands. [...]. None of these demands were met and now the Taliban will pay a price. By destroying camps and disrupting communications, we will make it more difficult for the terror network to train new recruits and coordinate their evil plans (BUSH, 2001, p. 75).

A investida norte-americana foi rápida e considerada um sucesso, pois os objetivos da missão foram alcançados - exceto pela captura do líder da al Quaeda, Osama bin Laden, que só foi alcançada 10 anos depois, durante o governo do sucessor de George W. Bush, o Presidente Barack Obama.

Não obstante, no que diz respeito à análise do caso, de acordo com a perspectiva da Teoria da Securitização, o processo de securitização foi um sucesso. Alcançou-se um amplo e difuso convencimento do público alvo acerca da necessidade da adoção de medidas emergenciais.

O tema do terrorismo, nos Estados Unidos da América, sofreu importantes mudanças, ao longo do Século XX. No início da Guerra Fria e durante parte do período quando ela desenvolveu-se, o tema do terrorismo 


\section{Artigo original}

Hegemonia - Revista Eletrônica de Relações Internacionais do Centro Universitário Unieuro

ISSN: $1809-1261$

UNIEURO, Brasília, número 14, 2014, pp. 25-87.

encontrava-se em posição considerada não-politizada. Ao final da Guerra Fria, o tema já podia ser considerado politizado, pois, por definição, encontrava-se presente nas principais discussões públicas da política interna estadunidense.

Verifica-se que, após os ataques do dia 11 de setembro de 2001 aos Estados Unidos da América, o tema do terrorismo foi, satisfatoriamente, alçado à categoria de assunto securitizado. Durante esse processo final de securitização, verifica-se que um discurso inicial caracterizou um ato ilocucionário e, portanto, voltado ao convencimento do público alvo da existência de uma ameaça à existência de um objeto referente, a saber, a cultura norte-americana (American way of life) e a liberdade do povo norteamericano.

A partir disso, os discursos passaram a constituir ato perlocucionário. Essa transformação deu-se ao passo que o discurso teve implicações práticas. A guerra do Afeganistão de 2001 foi a materialização do ato perlocucionário.

\section{CONCLUSÃO}

Conforme discutiu-se, no presente trabalho, verifica-se que o arcabouço normativo do Direito Internacional, em linha com a hermenêutica de seus princípios gerais, assegura aos Estados o direito à existência. Esse direito, como corolário do direito fundamental à independência, pode ser garantido por instrumentos de direito público autorizados por lei internacional.

É o caso do artigo 51 da Carta das Nações Unidas que, se, por um lado, confere aos Estados o direito de adotar medidas intervencionistas a fim de fazer cessar a ameaça, real ou iminente, à sua sobrevivência, por outro lado, elege a caracterização da real pertinência dessa ameaça ao status de condição sine qua non para o fim de dotar de legitimidade a sua ação defensiva.

Após os ataques realizados no dia 11 de setembro de 2001, o tema do 
Artigo original

Hegemonia - Revista Eletrônica de Relações Internacionais do Centro Universitário Unieuro

ISSN: $1809-1261$

UNIEURO, Brasília, número 14, 2014, pp. 25-87.

terrorismo passou a ser intensamente percebido como uma preocupação mundial e, mais que isso, uma ameaça à sobrevivência dos Estados soberanos modernos. Evidentemente, a ameaça terrorista já existia. Eventos, como o Massacre de Munique, em 1972, e o ataque à Embaixada de Israel, em Buenos Aires, em 1992, constituem prova dessa afirmação.

Com efeito, a partir dos eventos de 2001, a ameaça terrorista passou a ser percebida, mundialmente, em proporções extremamente maiores, sem precedentes na história mundial. Especificamente, nos Estados Unidos da América, os ataques de 2001 tiveram o condão de potencializar a percepção do terrorismo como uma ameaça, não somente, à sobrevivência do Estado norteamericano, mas, também, à própria forma de vida, à cultura e à liberdade do seu povo.

Uma vez detectada e identificada, no terrorismo, a ameaça, os organismos de administração estatal iniciaram um processo de contenção dela, que se consubstanciou, essencialmente, na Guerra do Afeganistão.

Não obstante, no interregno entre os ataques perpetrados, em território americano, e a investida norte-americana, no território afegão, verifica-se uma convergência de sucessivos elementos históricos de inenarrável relevância para a literatura que cuida dos temas de Segurança Internacional, para além da escolha da melhor estratégia de guerra.

À luz da Teoria da Securitização, que constituiu o foco do presente estudo, verificou-se que, para que um Estado possa adotar medidas extraordinárias - isto é, diferentes da dinâmica ordinária dos processos políticos e administrativos -, a fim de conter a ameaça à sua existência, ele necessita, precipuamente, convencer seu público alvo da existência dessa ameaça. Devese entender por público alvo, majoritariamente, o seu próprio povo; embora outros segmentos possam, igualmente, encaixar-se na mesma definição.

Constituiu o propósito fundamental do presente estudo aplicar os instrumentos de análise da Escola de Copenhague ao caso concreto da Guerra do Afeganistão. Nesse sentido, cuidou-se de perquirir se os organismos de 
Artigo original

Hegemonia - Revista Eletrônica de Relações Internacionais do Centro Universitário Unieuro

ISSN: $1809-1261$

UNIEURO, Brasília, número 14, 2014, pp. 25-87.

cúpula do governo norte-americano desenvolveram o papel de atores securitizadores e, mais ainda, se os discursos oficiais que orbitaram o ataque de 11 de setembro de 2001 foram aptos para elevar o tema do terrorismo à categoria de assunto securitizado e, ainda, identificar se houve ato-discurso apto produzir legitimação para a adoção de medidas militares emergenciais e extraordinárias, em estado de exceção.

Nesse sentido, impende concluir que houve, sim, os elementos de análise da Escola de Copenhague podem ser verificados na condução norteamericana das reações aos ataques de 11 de setembro de 2001. Com efeito, o ator securitizador foi o governo dos Estados Unidos da América, na pessoa de seu representante, o Presidente George W. Bush. Ele utilizou-se de discursos que foram cautelosamente preparados com a assistência ímpar de sua Conselheira de Segurança Nacional, Sra. Condoleezza Rice.

Por causa desses discursos, aqui identificados como atos-discurso (speech acts), o Congresso Norte-Americano e o povo daquele país foram levados a convencerem-se da necessidade de tomarem-se medidas urgentes e extraordinárias, para a contenção da ameaça terrorista, inicialmente, no Afeganistão, e, posteriormente, em outros locais do mundo.

Em todos os discursos ora analisados, pode-se visualizar o enfoque na condenação dos ataques e na promessa de perseguição da justiça retributiva. Com o apoio do Congresso e com a taxa de aprovação presidencial da população atingindo níveis nunca antes vistos na história dos Estados Unidos, o Presidente teve a confirmação da adesão do seu público alvo aos discursos de securitização.

Ainda no início deste trabalho, uma premissa foi levantada, a de que a percepção de uma ameaça pode incorrer na construção de um discurso securitizador com o objetivo de proteger existencialmente o objeto ameaçado. Essa premissa, como pode-se constatar no trabalho, é verdadeira. A construção do discurso de securitização do terrorismo, no caso em comento, teve a finalidade de proteger o modo de vida e a liberdade norte-americanos. A 
Artigo original

Hegemonia - Revista Eletrônica de Relações Internacionais do Centro Universitário Unieuro

ISSN: $1809-1261$

UNIEURO, Brasília, número 14, 2014, pp. 25-87.

necessidade de proteger esses objetos referentes partiu da percepção ou da detecção do terrorismo como ameaça significativa e iminente.

Essa premissa gerou, ainda, uma hipótese, segundo a qual quanto maior for a adesão do público-alvo ao ato-discurso, maior será a probabilidade de securitização de um objeto referente. A população norte-americana estava atormentada pelo medo de ver extintos os seus ideais. A Conselheira de Segurança Nacional, Sra. Condoleezza Rice, declarou, em recente obra de sua autoria, que o dia 11 de setembro de 2001 começou como um dia qualquer até que foi interrompido por um incidente.

O processo de securitização pode ser corroborado nas declarações que a Sra. Rice apresenta, em seu livro. Inicialmente, é relevante que ela afirme que a impressão geral, após a colisão da primeira aeronave, foi a de que se tratava de um mero acidente aeronáutico. Conforme novos aviões colidiam, aumentava-se e difundia-se o medo e o temor de novos ataques terroristas. A incerteza dos locais e do número de futuros ataques, ao tempo em que mais mortes de civis iam sendo contabilizadas, capitalizaram o sentimento geral de pânico, o que, naturalmente, catalisou a percepção da ameaça - necessária para a securitização do tema.

Em função da dinâmica dos fatos e das circunstâncias conforme as quais os eventos desenvolveram-se, em setembro de 2001, verificou-se que o público alvo estava, fluentemente, cada vez mais propenso à aceitação do discurso de securitização. Faltava, tão somente, a certeza que os discursos do Presidente dos Estados Unidos da América soube conferir à identidade dos inimigos do Estado, a saber, a organização terrorista al Caeda, o regime talibão e os espaços institucionais relevantes localizados no território afegão.

O processo de securitização somente perfectibiliza-se com a adesão do público alvo ao discurso securitizador. No caso dos Estados Unidos da América, verificou-se, mediante critério quantitativo e qualitativo de análise dos índices de aprovação presidencial, que a adesão do público alvo foi próxima da totalidade e, por esse motivo, a securitização do objeto referente deu-se de 
Artigo original

Hegemonia - Revista Eletrônica de Relações Internacionais do Centro Universitário Unieuro

ISSN: $1809-1261$

UNIEURO, Brasília, número 14, 2014, pp. 25-87.

forma bem sucedida. A identificação precisa do autor da ameaça proporcionou ao povo o último pedaço de informação necessário para a formação do convencimento, relativamente à necessidade de securitização do tema.

Destarte, foi possível verificar que, tal como preleciona a Escola de Copenhague, capitaneada pelo seu mais difundido autor, Barry Buzan, que as unidades de análise da Teoria da Securitização podem ser, claramente, identificadas nos eventos que orbitaram o processo decisório da incursão norteamericana na Guerra do Afeganistão de 2001. Assim, conclui-se que, tendo por base o presente estudo de caso, a hipótese inicial deste trabalho foi testada e aprovada. A adesão maciça do público alvo contribuiu para o sucesso do processo de securitização.

\section{REFERÊNCIAS}

BUZAN, Barry. Rethinking Security After the Cold War. Cooperation and Conflict, vol. 32, o 1, p. 5-28, 1997. Disponível em: <http://cac. sagepub.com/content/32/1/5. short>. Acesso em: 12 set. 2013.

BUZAN, Barry; HANSEN, Lene. The Evolution of International Security Studies. Cambridge: Cambridge University Press, 2009.

BUZAN, Barry; WFEVER, Ole; DE WILDE, Jaap. Security: A New Framework For Analysis. Colorado and London: Lynne Rienner Publishers, 1998.

COLOMBANI, J ean-Marie. Nous sommes tous Américains. Le Monde. [Editorial] Paris: 13 set. 2001.2 Disponível em: <http://www.lemonde.fr/idees/article/2007/05/23/nous-sommes-tousamericains 913706 3232.html >>. Acesso em: 10 out. 2013.

DE CARVALHO MOTTA, Bárbara Vasconcellos. Securitização do terrorismo e a produção de insegurança: a experiência da segunda Guerra do Iraque. Revista 
Artigo original

Hegemonia - Revista Eletrônica de Relações Internacionais do Centro Universitário Unieuro

ISSN: $1809-1261$

UNIEURO, Brasília, número 14, 2014, pp. 25-87.

Brasileira de Estudos de Defesa, v. 1, n. 1. Disponível em: $<$ http://www.seer.ufrgs.br/rbed/article/download/48976/30681>. Acesso em: 13 set. 2013.

DE PLÁCIDO E SILVA, Oscar Joseph. Vocabulário Jurídico. Rio de Janeiro: Forense, 1993.

DUQUE, Marina Guedes. A Teoria de Securitização e o processo decisório da estratégia militar dos Estados Unidos na Guerra do Iraque. 2008. $181 \mathrm{f}$. Dissertação (Mestrado em Relações Internacionais) - Universidade de Brasília, Brasília, 2008.

- O papel de síntese da escola de Copenhague nos estudos de segurança internacional. Contexto internacional, Rio de Janeiro, v. 31, n. 3, Dec. 2009. Disponível em: <http://www.scielo.br/scielo.php?script=sci arttext\&pid=S010285292009000300003\&lng=en\&nrm=iso>. Acesso em: 12 set. 2013.

ESTADOS UNIDOS DA AMÉRICA. The White House. The White House Archives. Selected Speeches of President George W. Bush: 2001-2008. Disponível em: $<$ http://georgewbushwhitehouse.archives.gov/infocus/bushrecord/documents/Selected_Speeches George_W_Bush.pdf>. Acesso em: 10 out. 2013.

ESTADOS UNIDOS DA AMÉRICA. United States Senate. The Library of Congress. Senate Joint Resolution 23 (2001). Disponível em: $<$ http://www.law.cornell.edu/background/warpower/sj23.pdf>. Acesso em 10 out. 2013.

FRIEDMAN, Thomas L. O Lexus e a Oliveira: Entendendo a Globalização. Rio de J aneiro: Objetiva: 1999, p. 25-51.

GASPAR, Carlos. A Guerra Fria Acabou Duas Vezes. NacãoNação e Defesa, no 
Artigo original

Hegemonia - Revista Eletrônica de Relações Internacionais do Centro Universitário Unieuro

ISSN: $1809-1261$

UNIEURO, Brasília, número 14, 2014, pp. 25-87.

105, - 2ª série, pp. 141-176, Verão 2013. Disponível em: $<$ http://www.idn.gov.pt/publicacoes/nacaodefesa/textointegral/NeD105.pdf>. Acesso em: 12 set. 2014.

GREENGRASS, Paul; BEVAN, Tim; FELLNER, Eric; LEVIN, Lloyd. Voo United 93. [Filme-vídeo]. Produção de Tim Bevan, direção de Paul Greengrass. Estados Unidos, Universal Pictures, 2006. Disponível em: <http://www.universalstudiosentertainment.com/united-93/>>. Acesso em: 10 out. 2013.

HAFTENDORN, Helga. The Security Puzzle: Theory-Building and DisciplineBuilding in International Security. International Studies Quarterly, vol. 35, no 1, p. 3-17, Mar. 1991. Disponível em: $<$ http:// www.jstor.org/discover/10.2307/2600386?uid=2\&uid=4\&sid=211046 19219377>. Acesso em: 12 set. 2013.

HISTORY CHANNEL. 9-11 Attacks. A timeline of the events on September 11, 2001. Nova Iorque: History Channel, 10 de outubro de 2013. Programa de TV. Disponível em: <http://www.history.com/topics/9-11-attacks>. Acesso em: 13 set. 2013.>

. Reaction to 9/11. Nova Iorque: History Channel, 10 de outubro de 2013. Programa de TV. Disponível em: <http://www. history.com/topics/9-11attacks>. Acesso em: 13 set. 2013.>

HUNTI NGTON, Samuel P. The Lonely Superpower. Foreign Affairs, vol. 78, $\mathrm{n}^{\circ} 2$, March/April, $\quad 1999, \quad$ p. 35-49. Disponível em: <http://www.jstor.org/stable/20049207>. Acesso em: 13 set. 2013.

HUYSMANS, Jef. Revisiting Copenhagen: Or, On the Creative Development of a Security Studies Agenda in Europe. European Journal of International Relations, vol. 4, № 4, p. 479-505, 1998b. Disponível em: <http://kar.kent.ac.uk/17369/>. Acesso em: 13 set. 2013. 
Artigo original

Hegemonia - Revista Eletrônica de Relações Internacionais do Centro Universitário Unieuro

ISSN: $1809-1261$

UNIEURO, Brasília, número 14, 2014, pp. 25-87.

MATHEWS, J essica T. Redefining security. Foreign Affairs, vol. 68, № 2, p. 162177, Spring 1989. Disponível em: <http://www.jstor.org/stable/20043906>. Acesso em: 13 set. 2013.

MOTTA, Bárbara V. C. Securitização do Terrorismo e a Produção de Insegurança: A Experiência da Segunda Guerra do Iraque. In: 10 Seminário Nacional de Pós-Graduação em Relações Internacionais, Brasília, 2012.

NAí M, Moisés. The five Wars of Globalization. Foreign Policy, J an./Feb. 2003, p. 29-37. Disponível em: <http://www.relooney.info/3040_c1070.pdf>. Acesso em: 13 set. 2013.

QUEIROZ, Fábio A. de. Hidropolítica e Segurança: As Bacias Platina e Amazônica em Perspectiva Comparada. Brasília: FUNAG, 2012.

RICE, Condoleezza. No Higher Honor: A Memoir of my Years in Washington. New York: Crown Publishers, 2011.

RUDZIT, Gunther; NOGAMI, Otto. Segurança e Defesa Nacionaisl: Conceitos Básicos Para uma Análise. Revista Brasileira de Política Internacional, vol. 53 (1), 2010, p. 5-24. Disponível em: $<$ http://www.scielo.br/pdf/rbpi/v53n1/a01v53n1.pdf>. Acesso em: 13 set. 2013.

SAINT-PIERRE, Héctor L. "Defesa" ou "Segurança"? Reflexões em Torno de Conceitos e Ideologias. Contexto Internacional, vol. 33, no 2, Jul/Dez. 2011, p. 407-433. Disponível em: <http://www.scielo. br/scielo.php?pid=S010285292011000200006\&script=sci arttext>. Acesso em: 13 set. 2013.

SARFATI, Gilberto. Teoria das Relações Internacionais. São Paulo: Saraiva, 2005

SHAW, Malcom N. International Law. Londres: Cambridge University Press, 
Artigo original

Hegemonia - Revista Eletrônica de Relações Internacionais do Centro Universitário Unieuro

ISSN: $1809-1261$

UNIEURO, Brasília, número 14, 2014, pp. 25-87.

2008.

TANNO, Grace. A contribuição da Escola de Copenhague aos Estudos de Segurança Internacional. Contexto Internacional, vol. 25, №1, Jan./J un. 2003, p. 47-80. Disponível em: <http://dx.doi.org/10.1590/S010285292003000100002>. Acesso em: 13 set. 2013.

ULLMAN, Richard H. Redefining security. International Security, vol. 8,no 1, p. 129-153, Summer $1983 . \quad$ Disponível em: <http://www.jstor.org/stable/2538489>. Acesso em: 10 out. 2013.

UNITED NATIONS. Charter of the United Nations. 1945. Disponível em: <http://www.un.org/en/documents/charter/>. Acesso em: 12 set. 2014.

WILLETTS, Peter. Transnational actors and international organizations in global politics. in BAYLIS, John; SMITH, Steve; OWENS, Patrícia. The Globalization of World Politics. A: an introduction to international relations. Nova Iorque: Oxford, 2011.

WILLIAMS, Michael C. Words, Images, Enemies: Securitization and International Politics. International Studies Quarterly, vol. 47, p. 511-531, 2003. Disponível em: <http://onlinelibrary.wiley.com/doi/10.1046/i.00208833.2003.00277.x/full>. Acesso em: 10 out. 2013. 